\title{
Yeni Buluntular Işığında Phaselis Epigrafi Çalışmaları
}

\author{
Epigraphical Studies in Phaselis in the Light of New Finds
}

\author{
Nihal TÜNER ÖNEN
}

open 2 access journals

PHASELIS: Disiplinlerarası Akdeniz Araştırmaları Dergisi'nde bulunan içeriklerin tümü kullanıcılara açık, serbestçe/ücretsiz "açık erişimli" bir dergidir. Kullanıcılar, yayıncıdan ve yazar(lar)dan izin almaksızın, dergideki makaleleri tam metin olarak okuyabilir, indirebilir, dağıtabilir, makalelerin çıktısını alabilir ve kaynak göstererek makalelere bağlantı verebilir.

PHASELIS: Disiplinlerarası Akdeniz Araştırmaları Dergisi uluslararası hakemli elektronik (online) bir dergi olup değerlendirme süreci biten makaleler derginin web sitesinde (journal.phaselis.org) yıl boyunca ilgili sayının içinde (Volume I: Ocak-Aralık 2015) yayımlanır. Aralık ayı sonunda ilgili yıla ait sayı tamamlanır.

Dergide yayımlanan eserlerin sorumluluğu yazarlarına aittir.

Makale Künyesi ～N. Tüner Önen, "Yeni Buluntular Işığında Phaselis Epigrafi Çalışmaları". Phaselis I (2015) 19-38. DOI: 10.18367/Pha.15002

Kabul Tarihi: 05.05.2015 | Online Yayın Tarihi: 12.06.2015

Editörya Phaselis Research Project

www.phaselis.org 


\title{
Yeni Buluntular Işığında Phaselis Epigrafi Çalışmaları
}

\author{
Epigraphical Studies in Phaselis in the Light of New Finds
}

\author{
Nihal TÜNER ÖNEN*
}

Öz: Buradaki makale, ilk olarak 1811 yılında keşfedilen Phaselis kentinin bugüne kadar bilim dünyasına tanıtılan ve bilimsel olarak yayınlanan epigrafik verilerini bir arada sunarak kentin epigrafi çalışmalarını bir araya getirmeyi ve 2012 - 2014 yılları arasında yürütülen Phaselis araştırmalarında tespit edilen yeni yazıtları bilim dünyasına tanıtmayı; bazı yazıtlar üzerinde corrigendum (düzeltme) ve addendum'lar (eklemeler) yapmayı amaçlamaktadır.

Anahtar sözcükler: Phaselis · Epigrafi · Onur Yazıtı · Mezar Yazıtı · Agon Yazıtı

Abstract: This paper gathers the epigraphical studies of the ancient city of Phaselis, discovered in 1811, by presenting all of the epigraphical data which have been published and introduced to the scientific world; to introduce the new inscriptions determined during the research conducted between 2012 and 2014; and to make corrigendum (correction) and addendum (addition) to some published inscriptions.

Keywords: Phaselis · Epigraphy · Honorary Inscription · Funerary Inscription · Agon Inscription

Phaselis kentinin epigrafi çalışmaları, modern araştırmacılardan kenti ilk keşfeden Kaptan F. Beaufort tarafından başlatılmıştır denilebilir. Zira Kraliyet Donanması adına yürütülen Küçük Asya'nın güney sahilinin ölçülmesi işi ile bağlantılı olarak 1811 ve 1812 yıllarında Phaselis'i ziyaret etmiş ve planını çıkarmış olan Beaufort, kentte yaptığı araştırmalarda yazıtlarla da meşgul olmuş ve yazıtlarda geçen $\Phi \alpha \sigma \eta \lambda i ́ n \eta \varsigma$ ethnikonundan dolayı bu yerleşimi antik Phaselis kenti ile özdeşleştirmiştir. Beaufort eserinde kentten iki yazıtı majuskel olarak yayınlamıştır ${ }^{1}$. 1838 yılında C. Fellows Hadrianus'a ithaf edilen anıtsal kapının ithaf yazıtının bir kısmını bulmuş ve Domitianus Agorası'nın ithaf yazıını yayınlamıştır ${ }^{2}$. Her iki araştırmacının az sayıda da olsa kentin yazıtlarını modern araştırmalara açması önemlidir. Kaydedilen söz konusu Phaselis yazıtları 1853 yılında Corpus Inscriptionum Graecarum $(C / G)$ serisinin üçüncü cildinde yayınlamıştır³.

Phaselis epigrafi çalışmalarına asıl ilgi bundan sonra gelişmiştir. Öyle ki 19. yüzyılın sonlarında ve 20. yüzyılın başlarında kente gelen ziyaretçiler dikkatlerini yazıtların keşfine çevirmişlerdir. 1874 yılında Attaleia'ya gelen G. Hisrchfeld, Consul Dionysios Vitalis'in evinde merdiven basamağı olarak kullanılmış olan Mausolos yazıtını bulmuş ve aynı yıl içinde bu yazıtı

\footnotetext{
* Yrd. Doç. Dr., Akdeniz Üniversitesi, Edebiyat Fakültesi, Eskiçağ Dilleri ve Kültürleri Bölümü, Antalya. nihaltuner@akdeniz.edu.tr

1 Beaufort 1818, 66 vd.

2 Fellows 1839, $211 \mathrm{vd}$.

3 CIG III 4324, 4332-4338.
} 
majuskel olarak yayınlamışıır ${ }^{4}$ A. Bezzenberger söz konusu yazıtı ilk minuskel yayınlayan kişi olmuştur ${ }^{5}$. Onun ardından F. Bechtel ve H. Collitz editörlüğünde yeniden değerlendirilen yazıt üzerinde $W$. Judeich yeni tamamlama önerilerinde bulunmuştur ${ }^{6} .1881$ ve 1882 yıllarında, 0. Benndorf ve çalışma arkadaşları tarafından Küçük Asya'nın güneybatısında yürütülen ilk araştırmaların ardından 1883/84 kışında Avusturya ekibinden F. von Luschan çalışmalara devam etmiştir. Her iki çalışmada da Phaselis kenti doğrudan ele alınmasa da yazıtlarına değinilmiştir. ${ }^{7}$ Aynı yıl içinde, Fransız bilim adamı V. Bérard da yerleşimi ziyaret ederek 1890 ve 1892 yıllarında Domitianus Agorası arşitrav yazıtını; Opramoas yazıtını; Q. Voconius Saxa ve oğlunu onurlandıran yazıtı; Korydalla ve Akalissos'luların Hadrianus onuruna diktikleri yazıtlar ile kentte pek çok memuriyet üstlenmiş Kolalemis'in onurlandırma yazıtı da dahil olmak üzere kentten 9 yazıtı yeniden değerlendirerek yayınlamıştır ${ }^{8} .1892$ yılında O. Benndorf, E. Kalinka ve diğer Avusturyalı araştırmacılar Phaselis'teki araştırmalarına devam etmişlerdir. R. Cagnat tarafından hazırlanmış olan Inscriptiones Graecae ad res Romanas pertinentes (IGR) serisinin üçüncü cildinde o güne kadar yayınlı olan 12 yazıt bir araya getirilmiştir ${ }^{9}$. 1908 yılında ise A. W. van Buran kentte kaydettikleri yayınlı/yayınsız 7 yazıtı yeniden ele almış ve yayınlamışı ${ }^{10}$. R. Paribeni ve P. Romanelli 1913 yıında kenti ziyaret etmiş ve imparator Caracalla'nın onurlandırılmasına ilişkin yazıt da dahil olmak üzere kaydettiği yazıtları yayınlamışıır ${ }^{11} .1921$ yılında Phaselis'e gelen ve Antalya'ya geri dönüş yolunda karadan giden C. Anti ise, ilk kez Phaselis teritoryumunda yazıt kaydetmiş ve bunları yayınlamıştır ${ }^{12}$. En nihayetinde E. Kalinka 1944 yılında hem kendisinin kaydettiği hem de o güne kadar yayınlanmış olan epigrafik verileri Tutili Asia Minoris serisinin ikinci cildinin üçüncü bölümünde bir araya getirmiş ve kısa bir kent tarihi yayınlamıştır ${ }^{13}$.

1968 yılında H. Schläger tarafından başlatılan, 1969 yılındaki ölümünden sonra J. Schäfer'ın idaresi altında devam ve Phaselis limanlarının topografik ve yapısal araştırmasını amaçlayan yüzey araştırmalarına epigraf olarak J. Blackman de katılıştır. Blackman kentte yaptığı çalışmalarda, daha önceden yayınlanmış olan yazıtların yerlerini yeniden lokalize etmek istemiş, fakat pek çok yazıtı yayınlarda tarif edilen yerlerinde bulamamış, yada çok farklı yerlerde tespit etmiştir. Blackman aynı zamanda dokuz yeni yazıt ile yayınlı yazıtlara ait yeni parçalar yayınlamışı ır ${ }^{14}$.

Phaselis'te 1980 yılında K. Dörtlük; 1981'den 1985 yılına kadar da C. Bayburtluoğlu yönetiminde kazı çalışmaları yapılmıştır. Dörtlük dönemi çalışmalarında herhangi bir epigraf görev almazken, Bayburtluoğlu başkanlığında yürütülen çalışmalara S. Şahin epigraf olarak katılmış ve yeni yazıtlar kaydetmiştir. 1999 yılında kentten bir atlet yazıtı yayınlayan S. Şahin ${ }^{15}$, daha

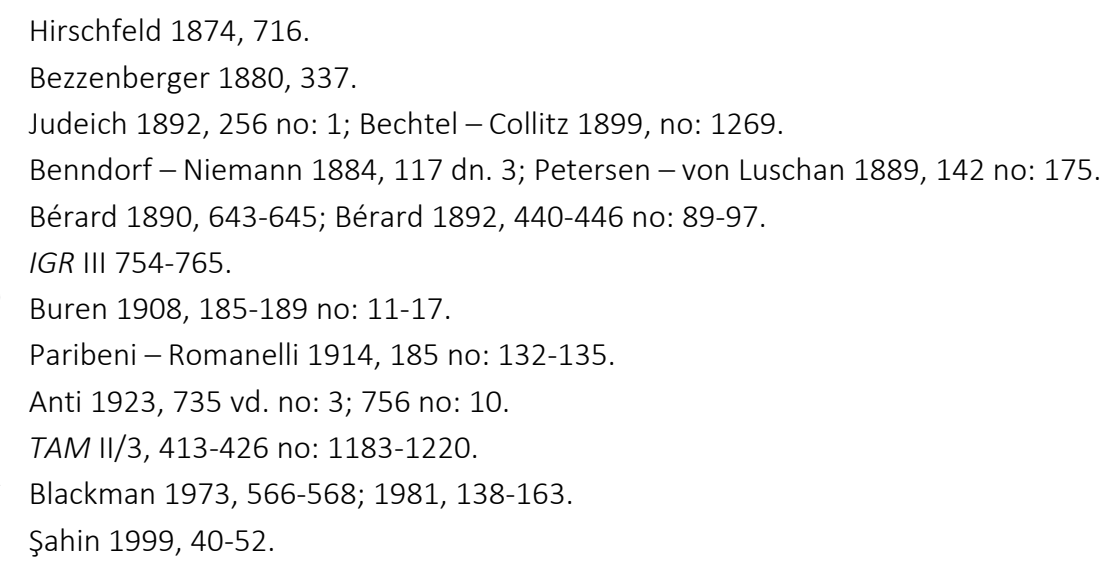


önceden kaydettiği 15 yeni yazıtı ise 2006 yılında M. Adak ve N. Tüner Önen ile birlikte yayınlamıştır ${ }^{16}$. N. Tüner Önen, "Phaselis Antik Kenti ve Teritoryumu" başlıklı doktora tezi kapsamında kent içinden ele geçmiş 66 adet Phaselis yazıtı ve yazıt parçasını geçmiş edisyonların her birini tekrardan gözden geçirerek değerlendirmiştir ${ }^{17}$. Phaselis'in epigrafi literatürü yukarıda verildiği şekilde özetlenebilir. Yaklaşık 200 yıldır aralıklarla devam eden araştırmalardan ele geçerek yayınlanmış olan söz konusu yazıtlar 1923 yılından itibaren Supplementum Epigraphicum Graecum (SEG) ciltlerinde de taranmışlardır ${ }^{18}$.

2012 yılından itibaren Akdeniz Üniversitesi Tarih Bölümü öğretim üyelerinden Prof. Dr. Murat Arslan'ın başkanlığında yürütülen Phaselis Antik Kenti ve Teritoryumu Yüzey Araştırmaları'nın epigrafi çalışmaları yine aynı üniversitenin Eskiçağ Dilleri ve Kültürleri Bölümü öğretim üyesi olan ve buradaki makaleyi kaleme alan Yrd. Doç. Dr. Nihal Tüner Önen başkanlığındaki ekip tarafından üstlenilmiştir. Yukarıda sözü edilen araştırma tarihçesinden de görüldüğg̈ü üzere Phaselis'ten ele geçen epigrafik malzemenin çoğu 19. yüzyıl sonu ve 20. yüzyılın başlarında kaydedilmiş ve yayınlanmışlardır. Bu edisyonlarda yazıtların buluntu yerleri hakkında genelde hiç bir bilgi verilmemektedir; bilgi verildiği durumlarda ise bu bilgi son derece muğlak, büyük oranda eksik ve hatta yanlış yönlendiricidir. Oysa yazıtların lokalizasyonu kalıntıların daha iyi bir şeklide anlaşılması hususunda oldukça önemlidir. Söz konusu yayınlarda yazıtların resimleri de çoğunlukla verilmemiştir. Sadece TAM II/3' de bazı yazıtların siyah beyaz resimleri verilmiş ve bazılarının çizimleri yapılmıştır. Bu sebeple Phaselis Antik Kenti ve Teritoryumu Yüzey Araştırmaları kapsamında sürdürülen epigrafi çalışmalarının birincil amacı bu güne kadar tespit edilememiş yazıtları bulmak ve kayıt altına alarak yayınlamak; ikincil amacı ise daha önce yayınlanmış yazıtları yerlerinde saptayıp, yeniden gözden geçirerek corrigendum (düzeltme) ve addendum'lar (eklemeler) yapıp değerlendirmek, estampajlarını alıp fotoğraflayarak envanterlemek ve gps koordinatlarını alıp kentin topografik haritasına aktararak kayıt altına almaktır.

\section{Yılı Çalışmaları}

2012 yılı araştırma sezonunda gerçekleştirilen çalışmalarda kentin ana caddesi üzerinde toplam 20 yazıt belgelenmiştir. Bunlardan 17'si daha önceden yayınlanmışlardır ${ }^{19}$. Söz konusu yazıtlar-

16 Adak et al. 2006

17 Tüner Önen 2008, 303-367.

18 SEG II 694; VI 742, 773; XVII 676; XXIX 1515; XXX 1529; XXXI 1297-1309; XLIX 1934; LV 1466-1480.

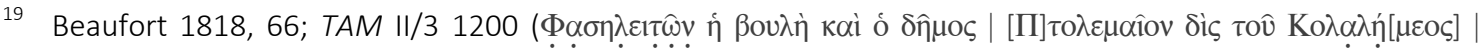

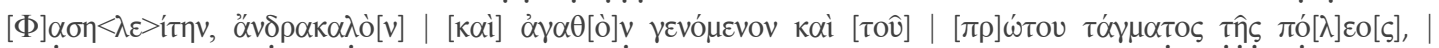

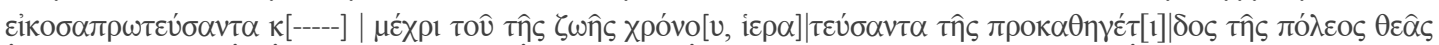

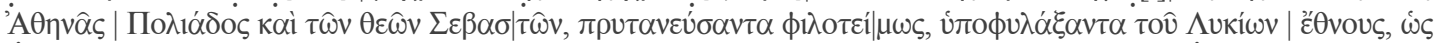

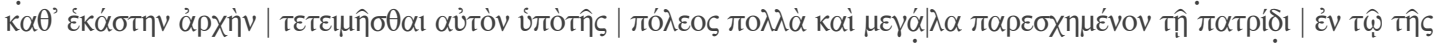

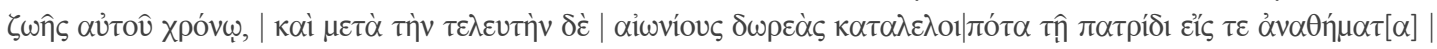

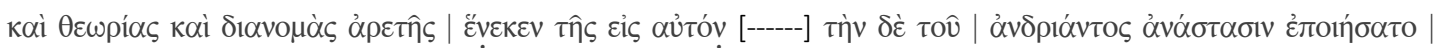

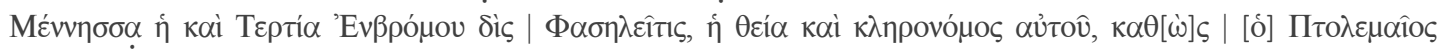

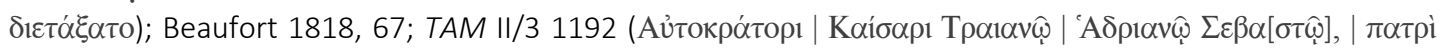

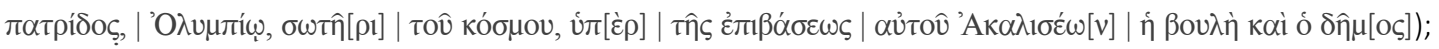

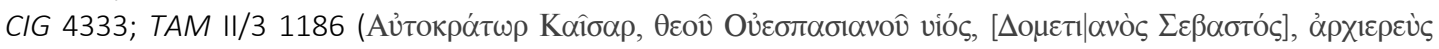

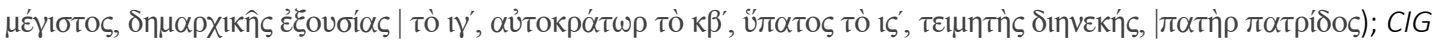

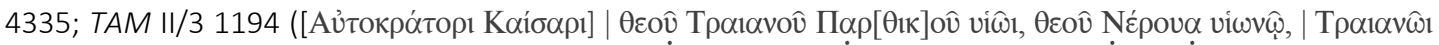
'A 
dan bir kısmının şu an bulunduğu yer in situ yerleri değildir. Zira 1982 yılı kazı çalışmaları sırasında güney limandaki Doğu Roma Dönemi rıhtımında devşirme malzeme olarak kullanılmış ya da Attaleia'ya götürülmek üzere limana indirilmiş yazıtlı blok taşlar buradan çıkarııp ana cadde kenarına sıralanmışlardır ${ }^{20}$. Buluntu yeri Kalinka ve Blackman tarafından tiyatro olarak verilen TAM II/3 1206 numaralı yazıt da Tetragonal Agora önünde ana cadde kenarına yerleştirilmiştir.

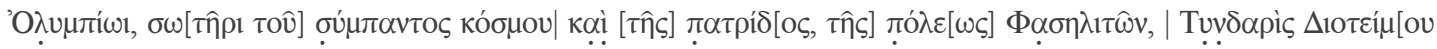

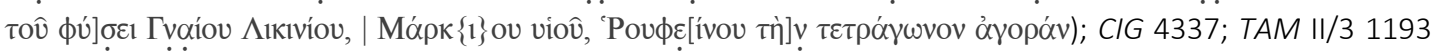

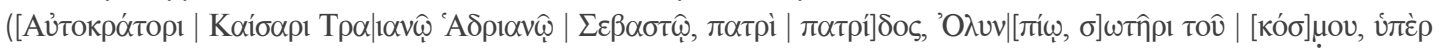

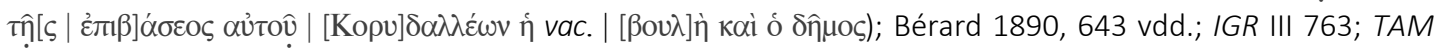

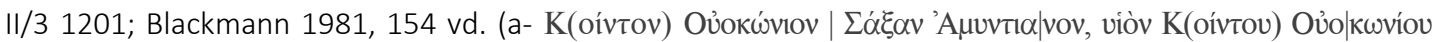

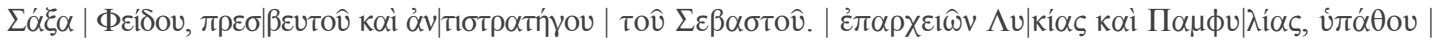

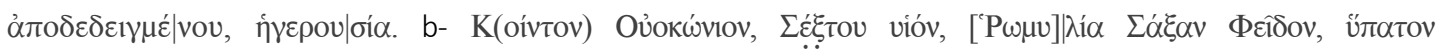

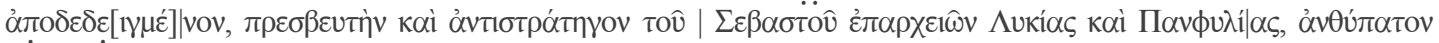

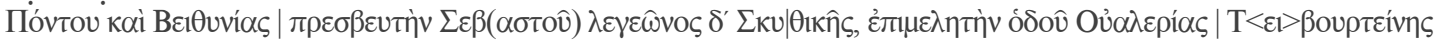

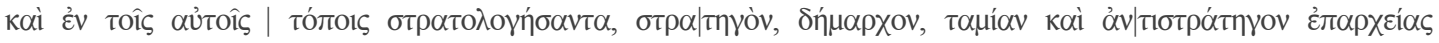

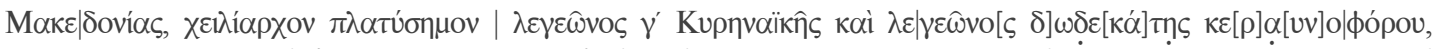

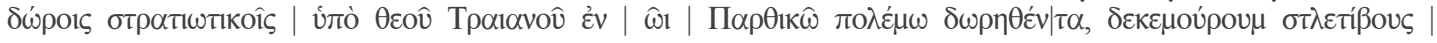

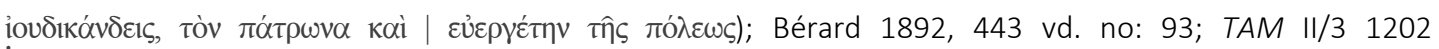

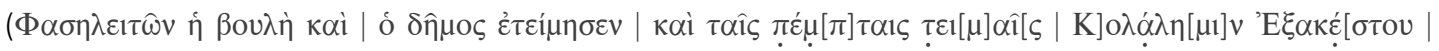

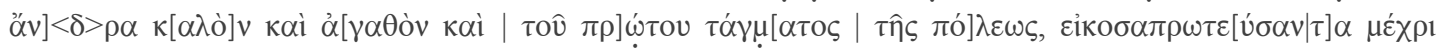

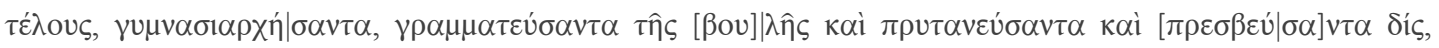

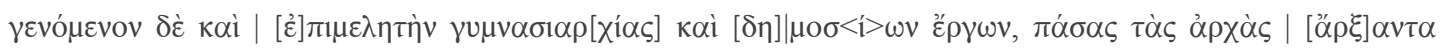

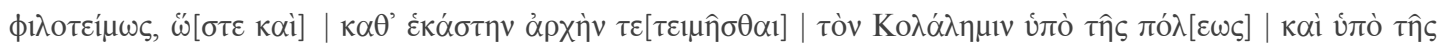

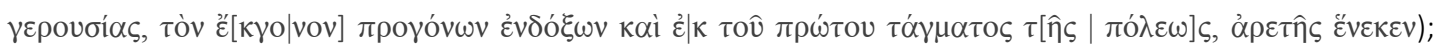

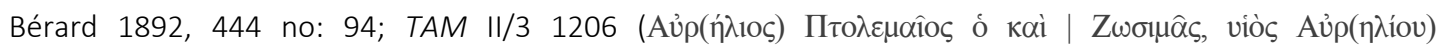

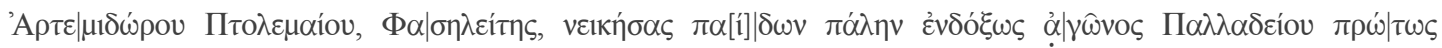

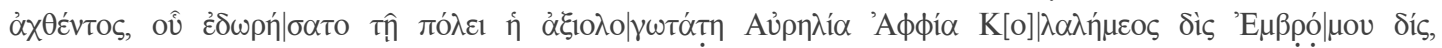

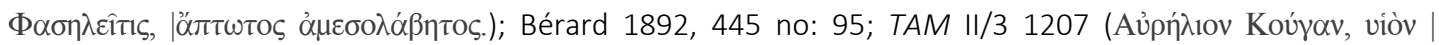

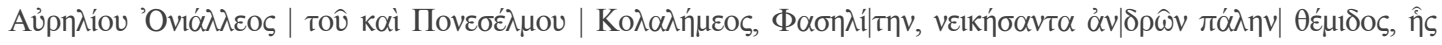

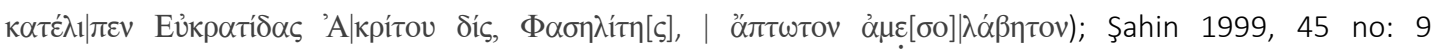

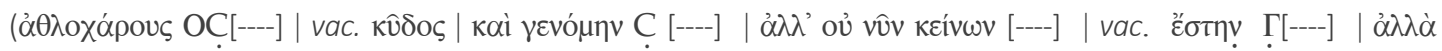

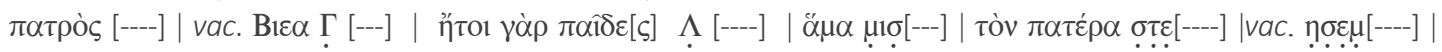

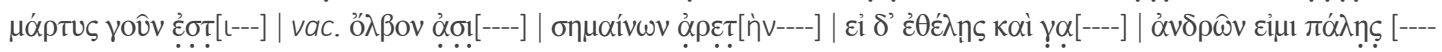

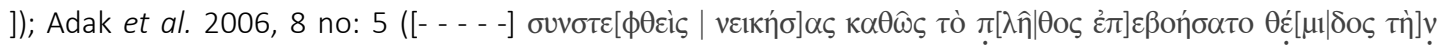

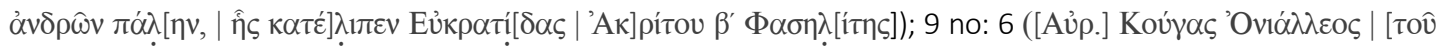

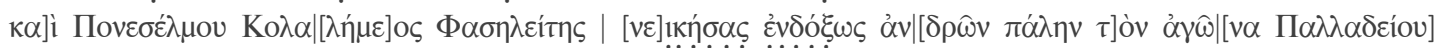

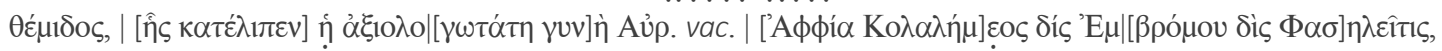

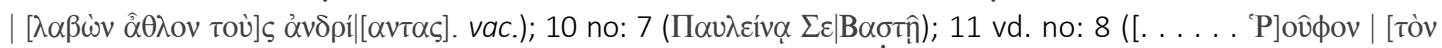

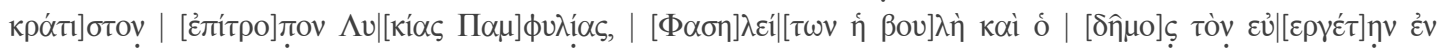

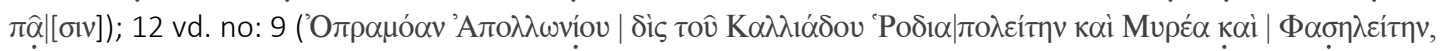

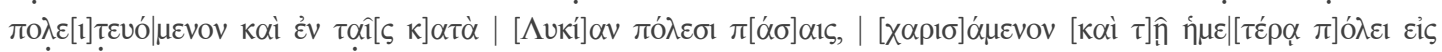

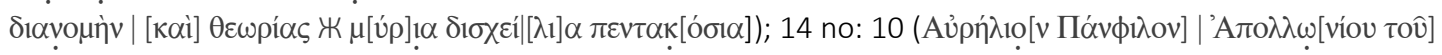

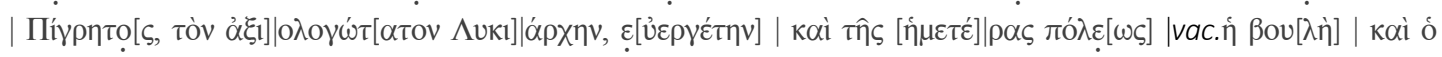

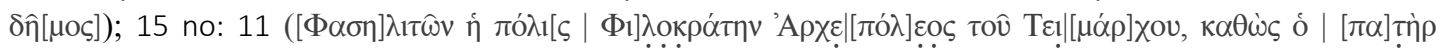

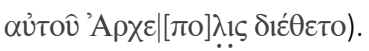

20 Bayburtluoğlu 1983, 182. Söz konusu yazıtlar şunlardır: TAM II/3 1206-1207; Şahin 1999, 45 no: 9; Adak et al. 2006, no: 5, 6, 8, 10 ve 11 . 
Bu alanda 3 yazıt yeni bulunmuştur. Yeni bulunan yazıtlardan ilkinin yüzeyi çok yıpranmış olduğundan ayrıntılı bir çalışma gerektirmektedir. İincisi ise adı yazıt üzerinde eksik, fakat baba

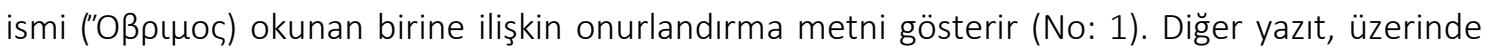
sadece halk meclisinin adının korunmuş olduğu bir fragmandır (No: 2).

Ana caddenin batı kenarında yer alan hamam kompleksinde yürütülen çalışmalarda daha önceden yayınlanmış olan iki yazıt yerlerinde tespit edilmiştir ${ }^{21}$.

Akropolis'te yürütülen 2012 yılı çalışmalarında yayınlı 8 yazıt yerlerinde tespit edilip kayıt altına alınmıştır ${ }^{22}$. Bu alanda $1^{\prime} i$ tam, 1'i fragman olarak iki yeni yazıt belgelenmiştir. illk yazıt tiyatronun güneyinden akropolise doğru devam eden merdivenlerin bitimindeki kule tarzı yapıda ikinci bir kullanıma tabi tutulmuştur. İinci kullanımı sırasında üstü sıvanan blok boyanmış ve üzerine yeniden bir yazı yazılmıştır. Oldukça tahrip olan boya ve yazının korunması için müzeden iki uzman çağrılmış ve blok üzerindeki boyalı kısmın sağlamlaştırma çalışması yapılmışıır². Söz konusu yazııın ilk kullanımı ise, sıvalı üst yüzeyin altından tespit edilen kısımlara göre, daha önceden yayınlanmış yazıtlardan tanıdığımız, Phaselis'e iki agon vakfeden ve kentin önde gelen şahsiyetlerinden olan Aurelia Apphia için yazıımış bir onur yazıtı taşımaktadır. Aynı zemine farkı dönemlerde yazılmış her iki yazıt üzerindeki çalışmalar devam etmektedir (Fig. 1-2). Diğer yazııın ise geç dönem karakteri gösteren beş harfi korunmuştur. Bu yazıt yeni bir sayısal fotoğraflama metodu olan Reflectance Transformation Imaging (RTI) yöntemi ile fotoğraflanarak yayınlanmışıı ${ }^{24}$.

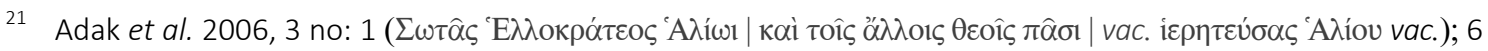

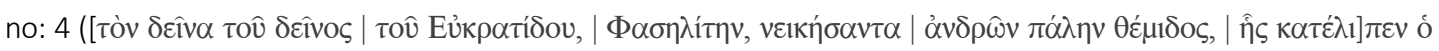

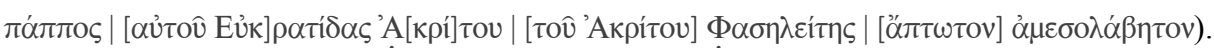

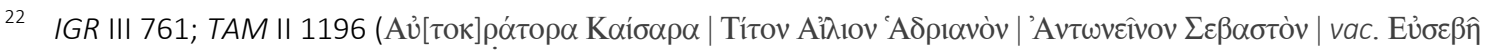

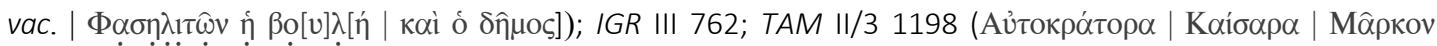

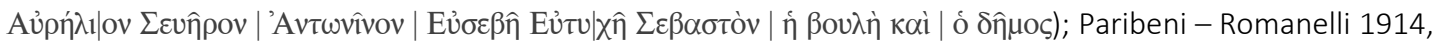

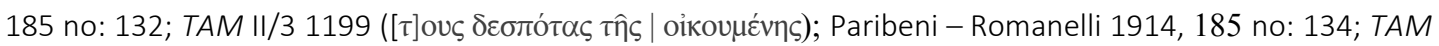

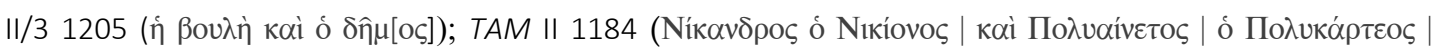

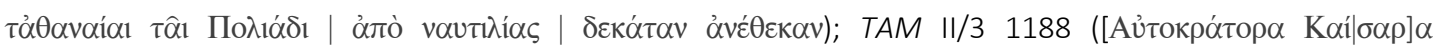

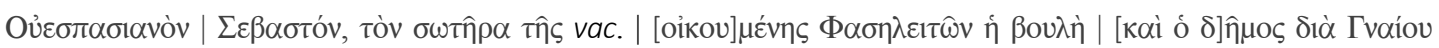

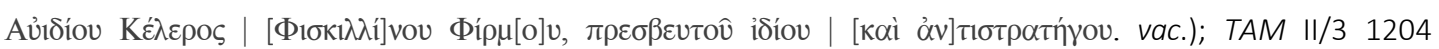

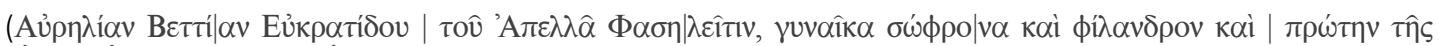

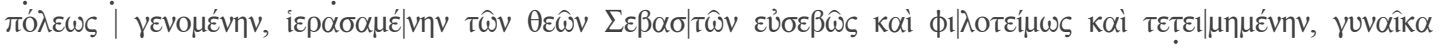

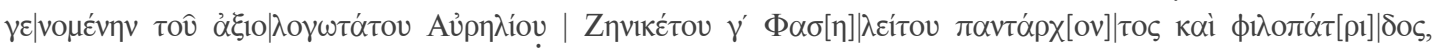

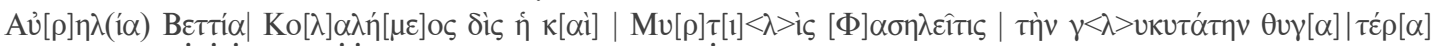

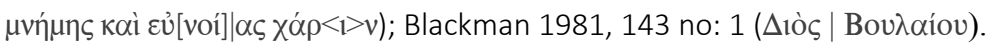

23 Arslan - Tüner Önen 2013, 82.

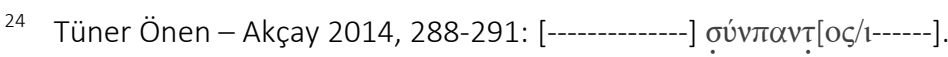




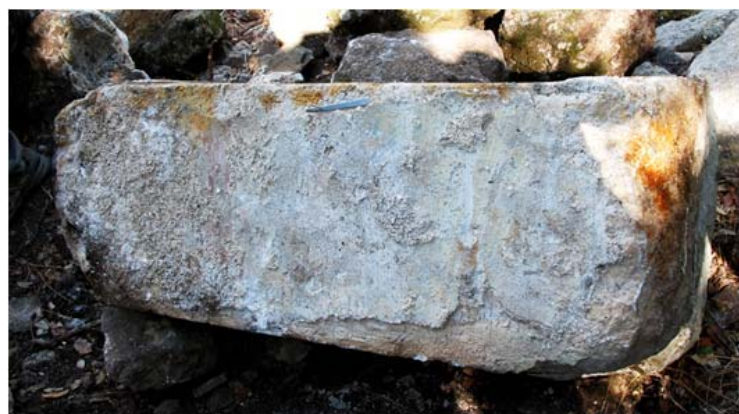

Fig. 1. Ikinci Bir Kullanıma Tabi Tutulmuş Yazıt

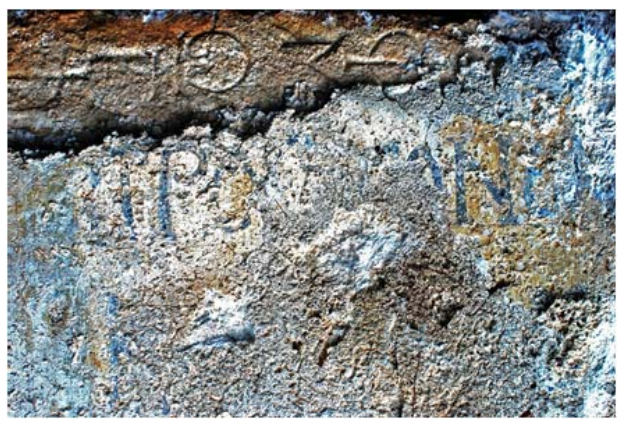

Fig. 2. Yazıt Ayrıntı

Hadrianus Takı ve Güney Liman etrafında yapılan araştırmalarda 5'i yeni 4'ü yayınlı 9 yazıt/yazıt parçası tespit edilmiştir ${ }^{26}$. Yeni yazıtlardan ikisi Roma İmparatoru Hadrianus'un M.S. 131-132 yıllarına denk düşen ikinci seyahatiyle ilişkili olarak imparatorun karısı Sabina ile kayınvalidesi Matidia'ya olan ithaf yazıtlarıdır²7. Diğeri Imparator Lucius Aurelius Verus'un Doğu Seferi'yle ilintili bir onurlandırmadır. Bu alanda imparator Hadrianus'un söz konusu seyahatine yönelik kentte yürütülen imar faaliyetleri kapsamında yapılmış olan Hadrianus Takı arşitrav blokları üzerindeki ithaf yazıtının bir parçası olup bu adamaya yönelik önceki çalışmaları doğrulayan bir fragman da ele geçen yeni yazıtlar arasındadır. 2012 yılı Phaselis Antik Kenti ve Territoriumu Yüzey Araştırması sırasında bulunan ve Phaselis'teki Hadrianus Takı ile çevresindeki düzenlemelere ait olan söz konusu 2 yazıt ve 1 fragman 2013 yılında ${ }^{28}$; Lucius Verus'a ilişkin yazıt ise 2015 yılında yayınlanmışlardır ${ }^{29}$.

Güney Limanında, rıhtımın güçlendirilmesi için yapılan geç dönem duvarında devşirme olarak kullanılmış olarak tespit edilen son yeni yazıt ise (Fig. 3), deniz suyu dolayısıyla oldukça tahrip olmuştur. Söz

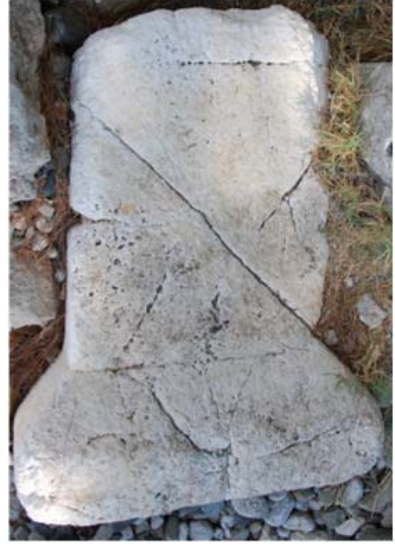

Fig. 3. Güney Limanda Devşirme Olarak Kullanılan Yazıtlı Kaide

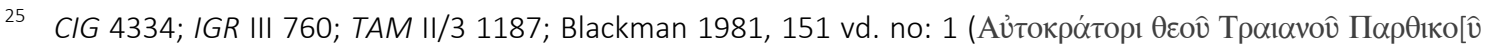

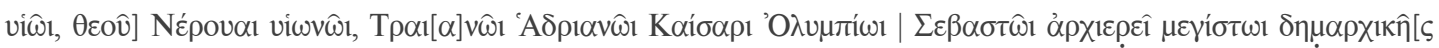

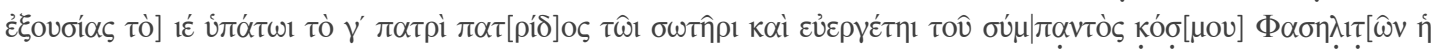

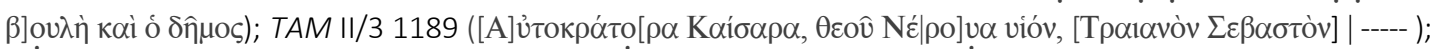

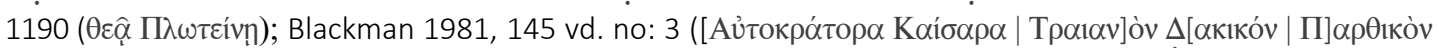

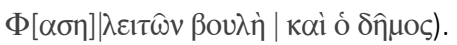

26 Arslan - Tüner Önen 2013, 82.

27 Phaselis'te Hadrianus'un kenti ziyaret etmesi nedeniyle hanedan üyelerine ithafen yazılmış iki yazıt bilinmekteydi. Bunlar Traianus'un karısı Plotina ve Hadrianus'un kız kardeşi Paulina içindi (TAM II 1190; Adak et al. 2006, 10 vd. no: 7). Yeni bulunan ithaflarla birlikte bu yazıtların sayısı dörde ulaşmıştır.

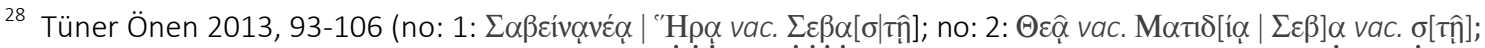

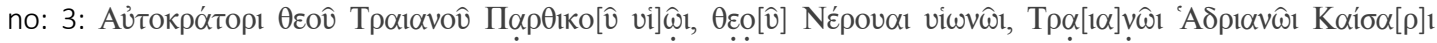

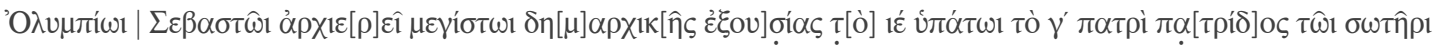

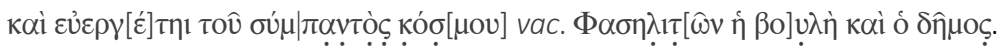

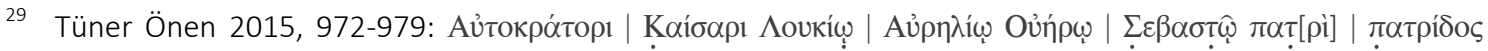

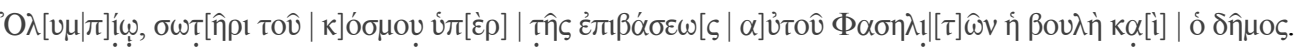


konusu yazıt 2015 yılı çalışmaları kapsamında RTI metoduyla fotoğraflanıp yeniden değerlendirilecektir.

\section{Yılı Çalışmaları}

2013 yılı araştırmaları kapsamında 5'i yeni 8 yazıt tespit edilmiştir ${ }^{30}$. Söz konusu yazıtlardan üçü E. Kalinka tarafından 1944 yılında TAM II/3 cildinde 1185, 1195 ve 1208 numaraları ile yayınlanmıştır ${ }^{31}$. Kalinka 1185 ve 1208 nolu yazıtların tiyatronun batısında, akropolis'in kuzey ucu yakınında -A theatro ad occidentem prope marginem arcis septemtrionalem inter ruderabulunduğunu kaydetmiştir (Fig. 4-5). Fakat alanda yapılan araştırmalarda söz konusu iki yazıt, Kalinka'nın not ettiği konumda bulunamamıştır. 1968/9 yılında kentte epigrafi çalışması sürdüren Blackman'ın de özellikle vurguladığı gibi Kalinka, TAM II/3'de yayınladığı Phaselis yazıtlarının lokalizasyonları konusunda büyük oranda eksik ve hatta yanlış yönlendirici bilgilendirmelerde bulunmuştur. Bundan dolayı bu yazıtlar Blackman tarafından da yeniden bulunamamıştı ${ }^{32}$. Kalinka'nın eserinde söz konusu yazıtların resimleri de verilmemiş, sadece çizimleri yapılmıştır.

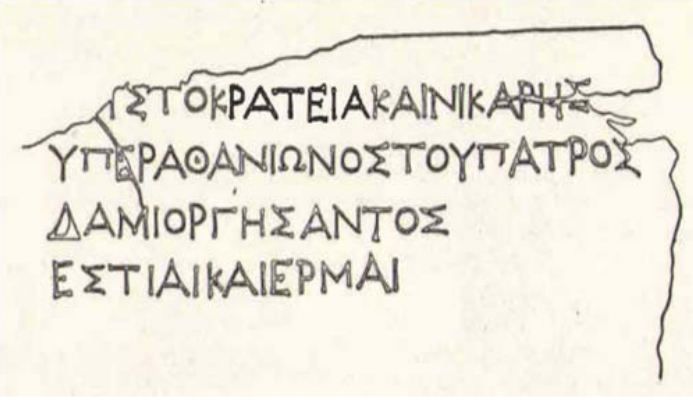

Fig. 4. TAM // 1185

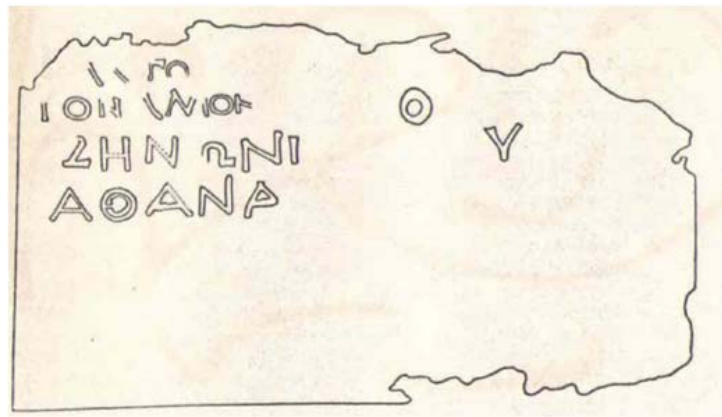

Fig. 5. TAM // 1208

Akropolis üzerinde yürüttüğümüz çalışmalarda her iki yazıt da akropolis'in batı eteklerinde, tiyatronun yaklaşık 120 - 130 metre kadar güney-güneybatısında konumlanan, içerisinde ve yakınında daha önceden yayımlanmış olan Zeus Boulaios, imparatorlar Vespasianus ve Caracalla ile evrenin efendilerine ait yazıtların yer aldığı alanda bulunmuştur. TAM II/3 1185 nolu yazıt Hestia ve Hermes için bir adak yazıtı taşır (Fig. 6). Olumsuz hava şartları dolayısıyla yazıt yüzeyinin çok aşındığı tespit edilmiştir. 1195 nolu yazıt ise Tyndaris isimli bir Phaselis'li bayanın imparator Hadrianus'u onurlandırma yazıtını taşır. 1208 nolu yazıtın yüzeyi de oldukça aşınmıştır, bu sebeple içeriği tam olarak anlaşılamamıştır (Fig. 7). Aşınmalar dolayısıyla okunamayan söz konusu yazıtlar üzerinde 2015 araştırma sezonunda RTI metodu ile fotoğraflama çalışmaları yürütülerek, içeriklerinin kontrol edilmesi ve gerekli corrigendum (düzeltme) ve addendum'ların (eklemeler) yapılması planlanmaktadır.

30 Arslan - Tüner Önen 2014, 193 vd.

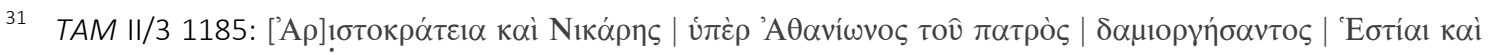

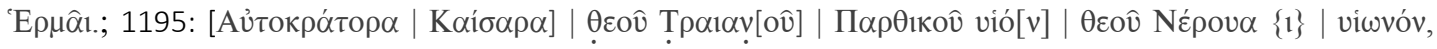

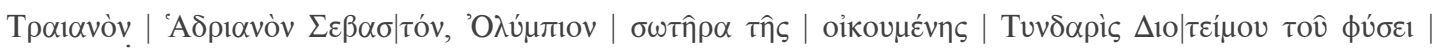

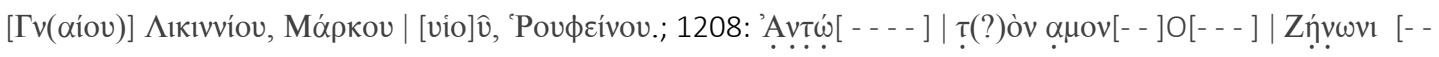
- -] |'A $\theta \alpha v \alpha[----]$.

32 Blackman 1981, 139. 


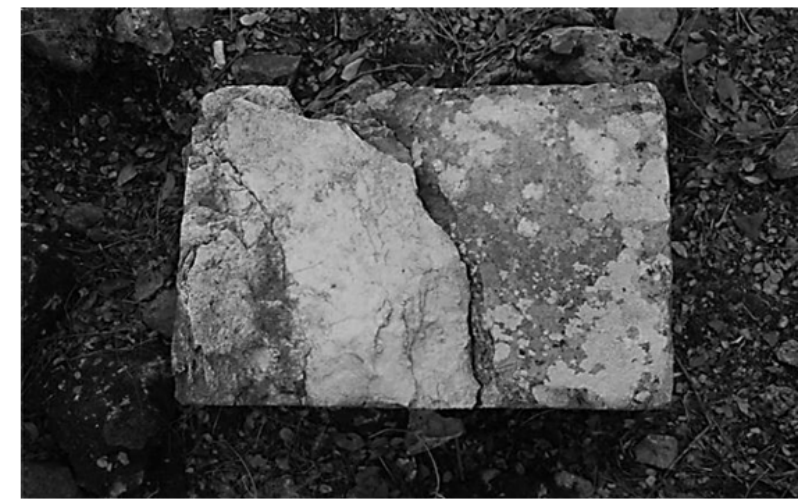

Fig. 6. Hestia-Hermes için Adak Yazıtı (TAM II/3 1185)

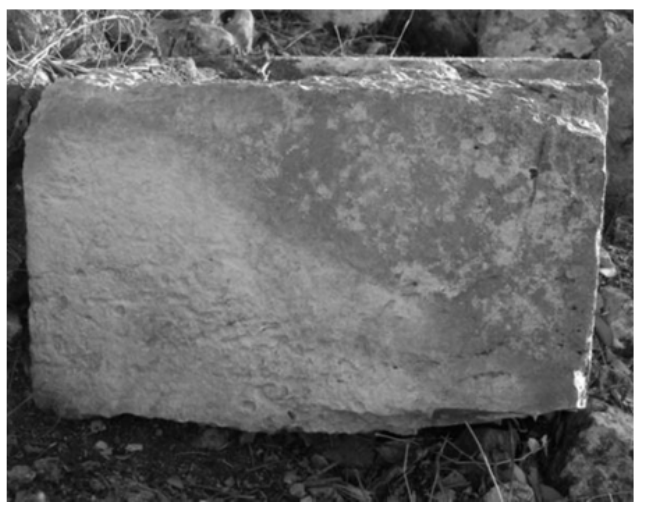

Fig. 7. TAM II/3 1203

2013 araştırma sezonunda akropolis'in güneybatı etekleri üzerinde arkaik dönem harf karakteri gösteren ve dor diyalektinde yazılmış bir adak yazıtı tespit edilmiştir. Yazıtın içeriğine göre, Euphanes isimli bir vatandaş sahip olduklarının 1/10'unu Athena Polias'a verdiğini beyan eder. Söz konusu yazı 2015 yııında tarafımızdan yayınlanmışıır ${ }^{33}$. Bu yazıt Phaselis kentinde şimdiye kadar bulunmuş en erken yazıttır. Bu durum Phaselis'in gerçekten de Arkaik Dönem bir kent olduğunu somut olarak belgelemekte ve bölgenin yerleşim tarihini değerlendirme konusunda kesin sonuçlara ulaşılması hususunda çok değerli katkılar yapmaktadır. Aynı yıl içinde akropolis üzerinde bulunan diğer bir yazıt ise kim olduğu tespit edilemeyen bir imparatora ithaf edilmiş ve arşitrav blokları üzerine yazıımış bir ithaf yazıtı taşır (Fig. 8). Tam olarak tümlenemeyen söz konusu yazıt 11 parçadan oluşur.
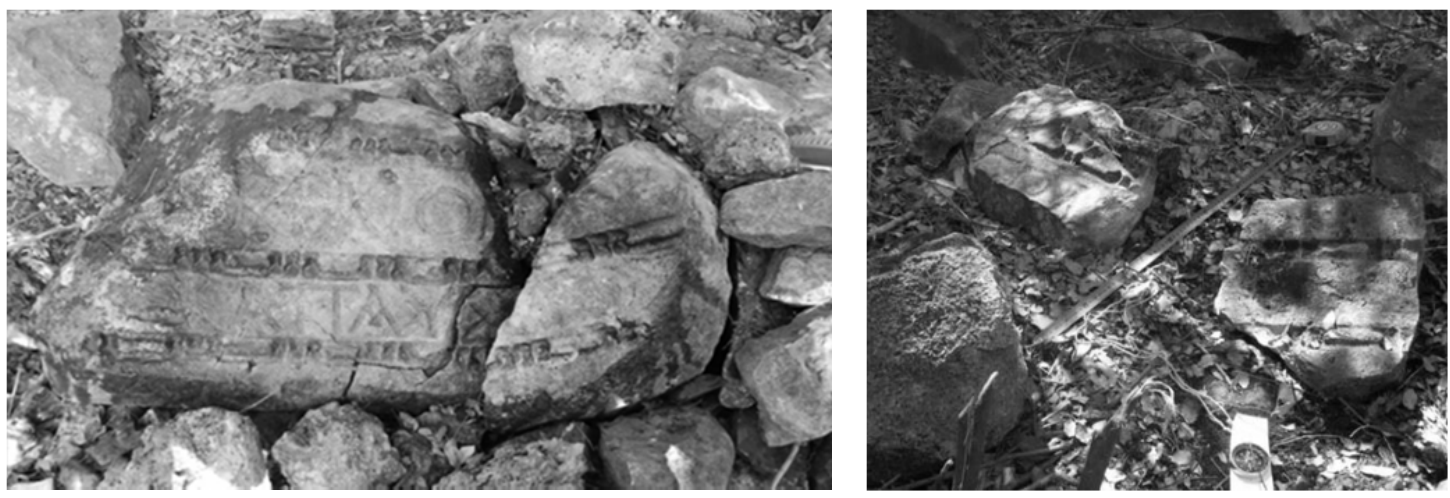

Fig. 8. Kim Olduğu Tespit Edilemeyen bir Imparatora Yapılan Ithaf Yazıtının Fragmanları

Akropolis üzerinde yürütülen çalışmalarda yazıtlı bir heykel kaidesinin üst kısmı tespit edilmiştir (No: 3). Söz konusu fragman, daha önce Kalinka tarafından yayınlanan ve Tyndaris isimli bir Phaselis'li bayanın imparator Hadrianus'u onurlandırma yazııını taşıyan yazııın (TAM II/3 1195) yakınında bulunmaktadır. Yayınılı yazııın ilk iki satırının eksik olması ve her iki kaidenin ölçülerinin birbirini tutması, yeni bulunan parçanın TAM II/3 1195 nolu yazııı üst parçası olduğunu düşündürmektedir.

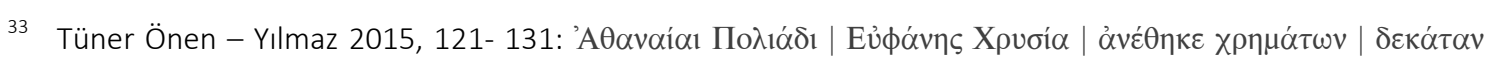
$\varepsilon \dot{\xi} \xi \alpha_{\mu} \mu \varepsilon v o s$. 


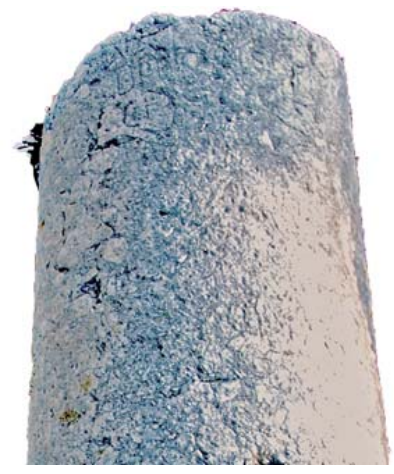

Fig. 9. M.S. III-IV. Yüzyıla Tarihlendirilen Yazıt

Ana caddede yürütülen çalışmalarda ise, sütun formlu bir stel üzerinde, ortografik açıdan değerlendirildiğinde M.S. III. yüzyılın son çeyreği ile M.S. IV. yüzyıla tarihlenebilecek harf karakterleri gösteren yeni bir yazıt tespit edilmiştir. Yazıt yüzeyi oldukça aşınmış olduğundan, söz konusu yazıt üzerinde değerlendirme çalışmaları devam etmektedir. 2013 araştırma sezonunun son buluntusu ise Güney Liman'da, geç dönemde yapılan rıhtım yapısında devşirme malzeme olarak kullanılan bir agon yazıtı taşıyan heykel kaidesidir. Söz konusu yazıt Eukratidas'ın kente vasiyet ettiği agonda düzenlenen yarışları kazanan birininin onurlandırılmasını içerir (No: 4).

\section{Yılı Çalışmaları}

2014 yılı epigrafi çalışmaları Kuzeydoğu Nekropolis, Merkesi Liman ve çevresi, Ana Cadde ve Güney Liman ile akropolis'te devam ettirilmiştir ${ }^{34}$. Nekropolis'te tespit edilen 3 yazıtın 2'si Blackman tarafından 1981 yılında yayınlanmıştır ${ }^{35}$. Kuzey nekropolis'te tespit edilen son yazıt ise tarafımızdan yeni bulunmuştur (No: 5). Askeri liman olarak adlandırılan Merkezi Liman ile aquaeductus arasındaki alanda yer alan ve muhtemelen de depo olarak planlanmış yapı kalıntıları arasında sürdürülen çalışmalarda ise Serapion isimli bir Phaselis'linin babası ile birlikte temelinden itibaren inşa ettirdikleri bir meskene ilişkin yazıt tespit edimiştir (No: 6). Akropolis üzerinde, 2005 yılında yayınlanmış olan Apollon latros'a adanmış adak yazıtı yeniden bulunarak yerinde fotoğraflanmış ve envanterlenmiştir ${ }^{36} .2014$ yılı araştırmalarında son olarak tiyatronun skene binası kalıntıları arasında daha once Bérard $^{37}$ tarafından yayınlan ve muhtemelen tiyatronun inşa yazıtına ait olabilecek yazıt parçası bulunmuş ve envanterlenmiştir. Yazıtta

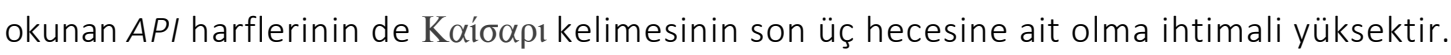

\section{Yeni Yazitlar}

\section{No: 1- Obrimos Oğlu [...]ara[t]os İçin Onurlandırma}

2012 yılı araştırmaları sırasında kent limanı girişinde ana caddenin batı kenarındaki basamaklı kısımda bulunmuş, kireçtaşından heykel kaidesi. Sadece sağ bölümü korunmuş, köşelere köşe akroterleri işlenmiş ve üstten (muhtemelen alttan da) profillendirilmiştir. Üzerinde kısmen 3

34 Arslan - Tüner Önen 2015, 205 vd.

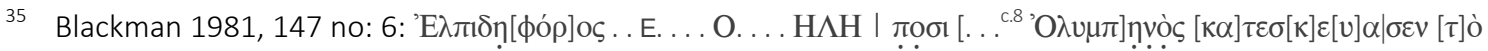

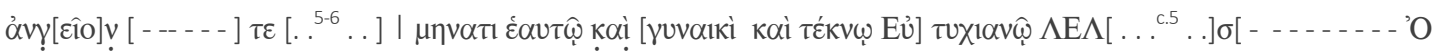

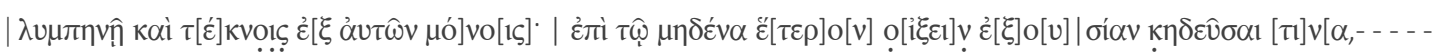

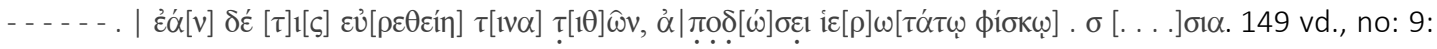
'Họóф̣!

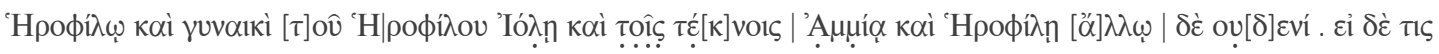

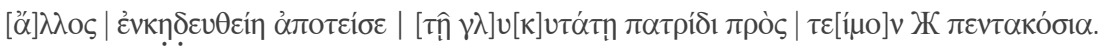

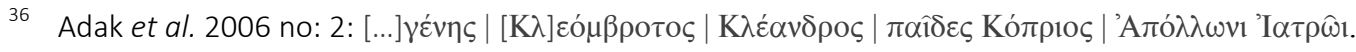

37 Bérard 1982, 443 no: 92: API. 
satır yazıt korunmuştur. Yazııı buraya nereden getirildiği bilinmemekle birlikte, diğer heykel kaideleri gibi Güney Limanı́ndan getirilmiş olma olasılı̆ı̆ bulunmaktadır.

Yük.: 0,55 m.; Gen.: 0,49 m.; Der.: 0,43 m.; Harf Yüksekliği: 0,026-0.028 m.

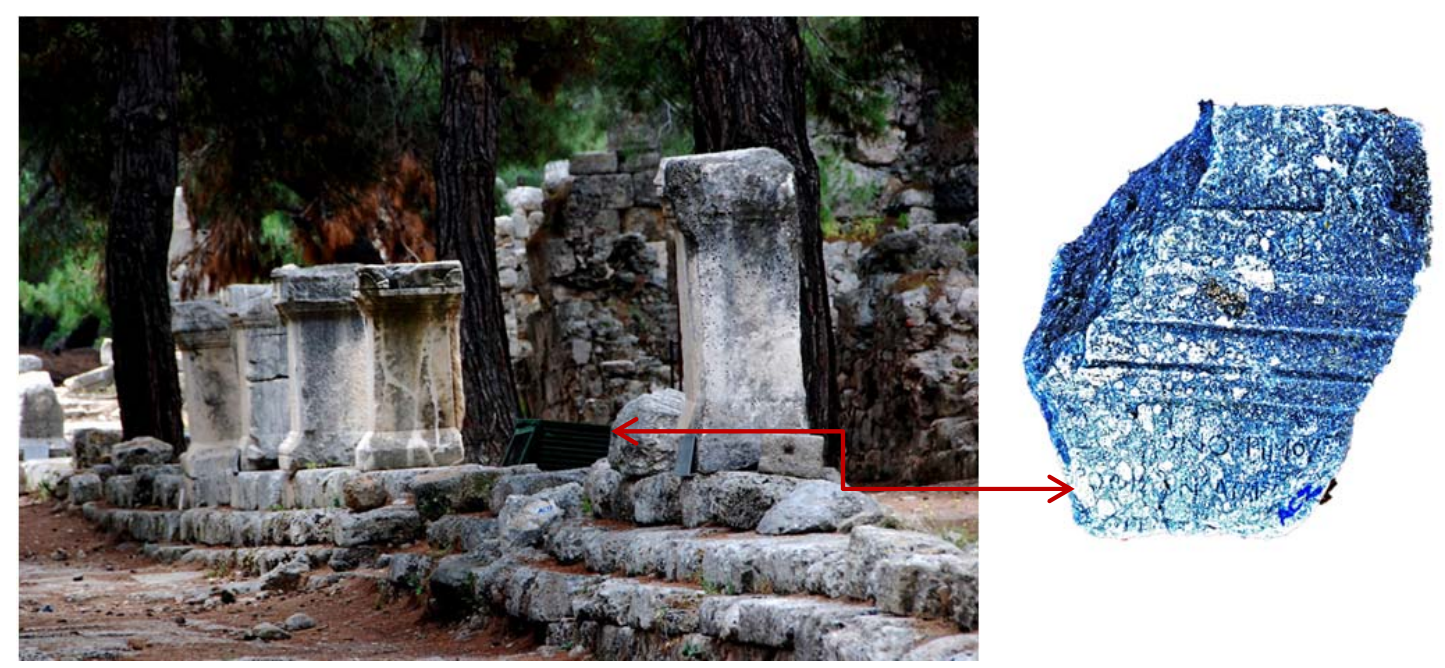

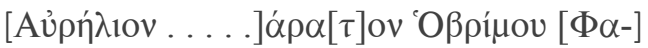

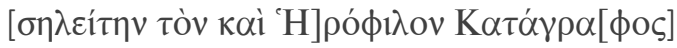

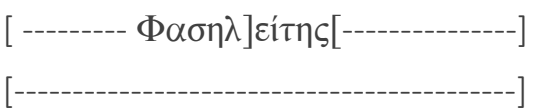

Falanca oğlu Phaselis'li Katagrafos

Obrimos oğlu Aurelius .......aratos'u?

namı diğer Herophilos'u

(onurlandırdı).

Tarih: M.S. II-III. yüzyıl.

Str. 1:Illk satırda kırık kısımdan sonra korunan APA.ON harfleri, accusativus casusta bir şahıs

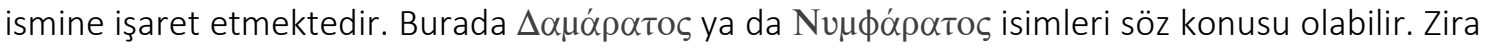
her iki isim kentin Hellenistik Dönem sikkeleri üzerinde belgelenmiştir ${ }^{38}$. Bu isimler dışında

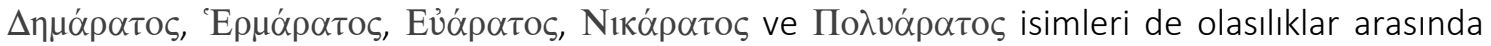
sayllabilir ${ }^{39}$.

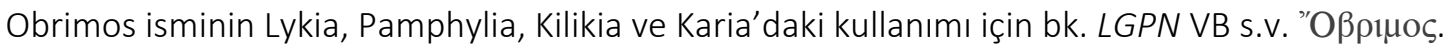

Str. 2: Bu satırda korunan ilk harfler-POФI $\Lambda \mathrm{ON}$ - da yine accusativus casusta bir şahıs ismine işaret etmektedir. Söz konusu isim muhtemelen onurlandırılan şahsın ikinci ismi, yani lakabı ol-

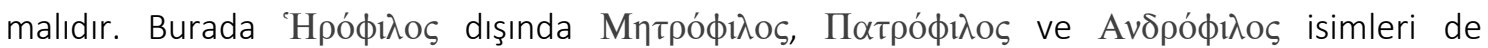

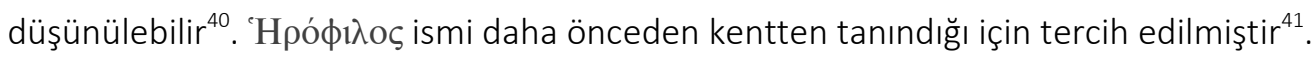

Söz konusu lakabı takip eden harfler-KАТАГРА- bir alt satırda nominativus casusta verilen

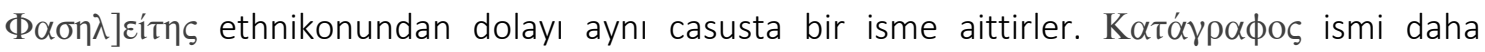

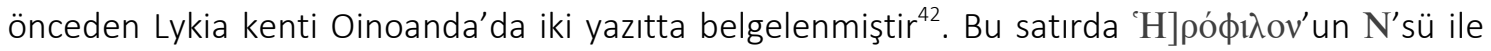

38 Heipp-Tamer 1993, 124 seri 8d ve no: 347.

39 Diğer olasılıklar için ayrıca bk. Dornseiff - Hansen 1957, 287.

40 Diğer olasılıklar için ayrıca bk. Dornseiff - Hansen 1957, 257.

41 Blackman 1981, 149 vd. no: 9.

42 IGR III 499; Holleaux 1886, 234 no: 14. 


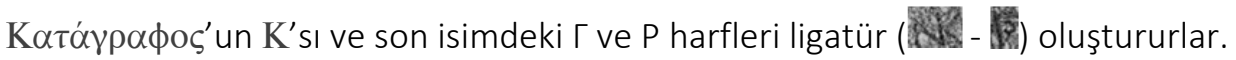

\section{No: 2- Fragman}

2012 araştırmaları sırasında, Tetragonal Agora kapısının güney kısmında, Opramoas yazııının arkasında bulunmuştur. Her yönden kırık olan parça, bir onur ya da ithaf yazııının son satırına ait harfleri taşımaktadır.

Yük.: 0,27 m.; Gen.: 0,36 m.; Der.: 0,16 m.; Harf Yüksekliği: 0,045-0,050 m.

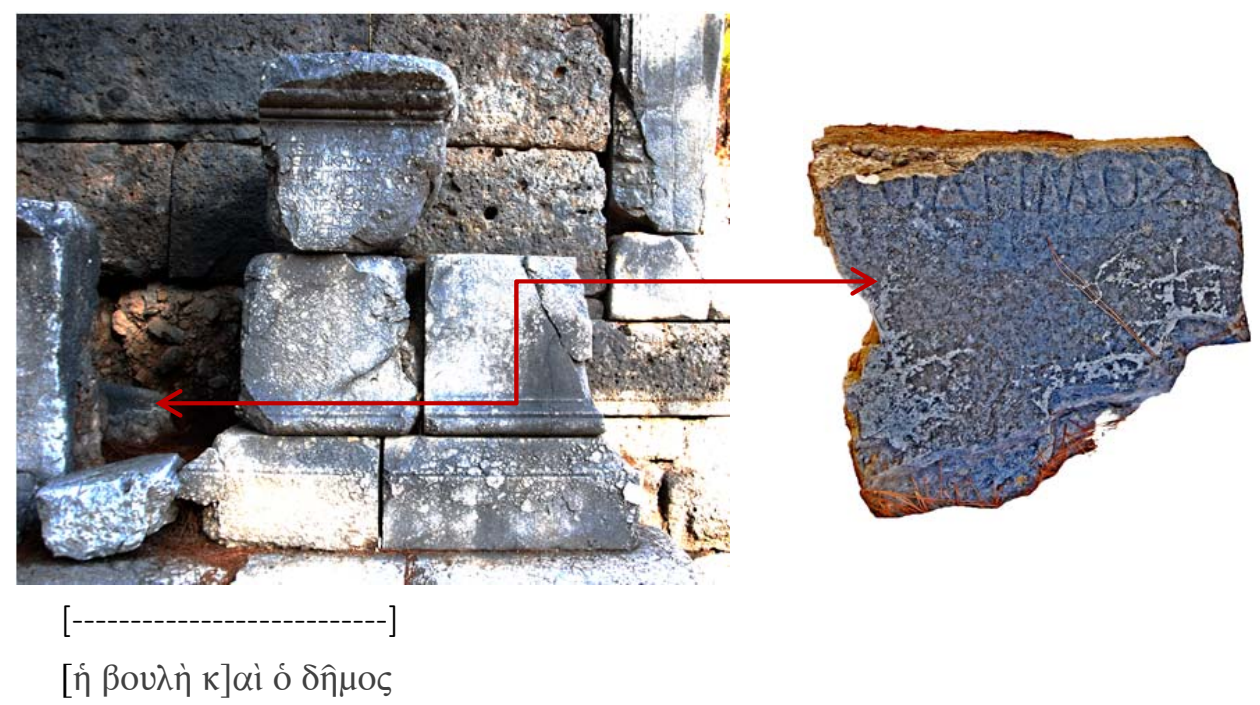

\section{No: 3- Yazıtlı Heykel Kaidesi}

Akropolis'in güneybatı köşesinde, Güney Liman'a hakim bir konumda yer alan ve Doğu Roma Hıristiyanlık Dönemi'ne tarihlenen bazilikal planlı klise yapısının güney nef duvarının hemen yakınında bulunmuştur. Kireç taşından profilli ve köşeleri akroterli, alttan ve yanlardan kırık heykel kaidesinin üst kısmı. Sağ ön köşeye ait parça da hemen yanında bulunmuştur. Alt kısımdadübel deliği var. Tek satır yazıtı korunmuştur.

Yük.: 0,40 m.; Gen.: 0,57 m.; Der.: 0,54 m.; Harf Yüksekliği: 0,05 m.

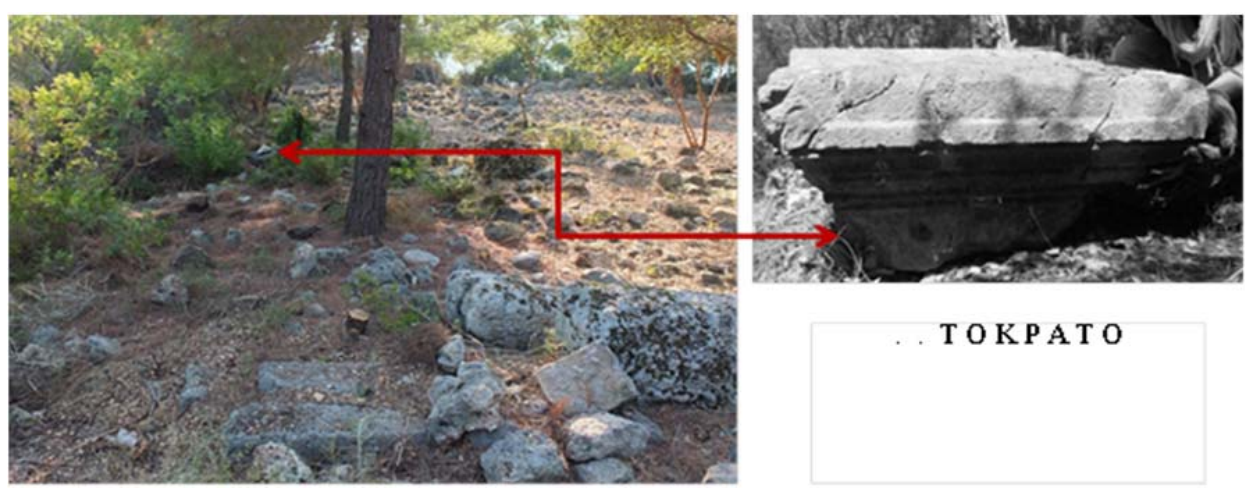

Batı kısımlarda istinat duvarlarıyla güçlendirilmiş bir düzlük üzerinde bulunan klisenin söz konusu istinat yapısı, akropolis'in bu kısımdaki dik yamacı dolayısıyla zaman içinde çökmüştür. Kilisenin yamaca çökmüş kalıntıları arasında bulunan ve bir heykel kaidesinin yazıtlı bölümüne ait parçanın yeni bulunan fragmanın alt kısmı olduğu düşünülmektedir. Zira her iki yazıt hemen hemen aynı boylam üzerinde bulunmaktadır. Bazilikanın çöken kısmında bulunan yazıt daha ön- 
ceden yayınlıdır (IGR III 758; TAM II/3 1195). Söz konusu kaide parçasının boyutları (gen.: 0,58 m.; der.: 0,55 m.; harf yüksekliği: 0,05-0,055 m.), üzerinde bulunan dübel deliği ve ilk iki satırının bulunmayışı bu düşünceyi doğrulamaktadır.

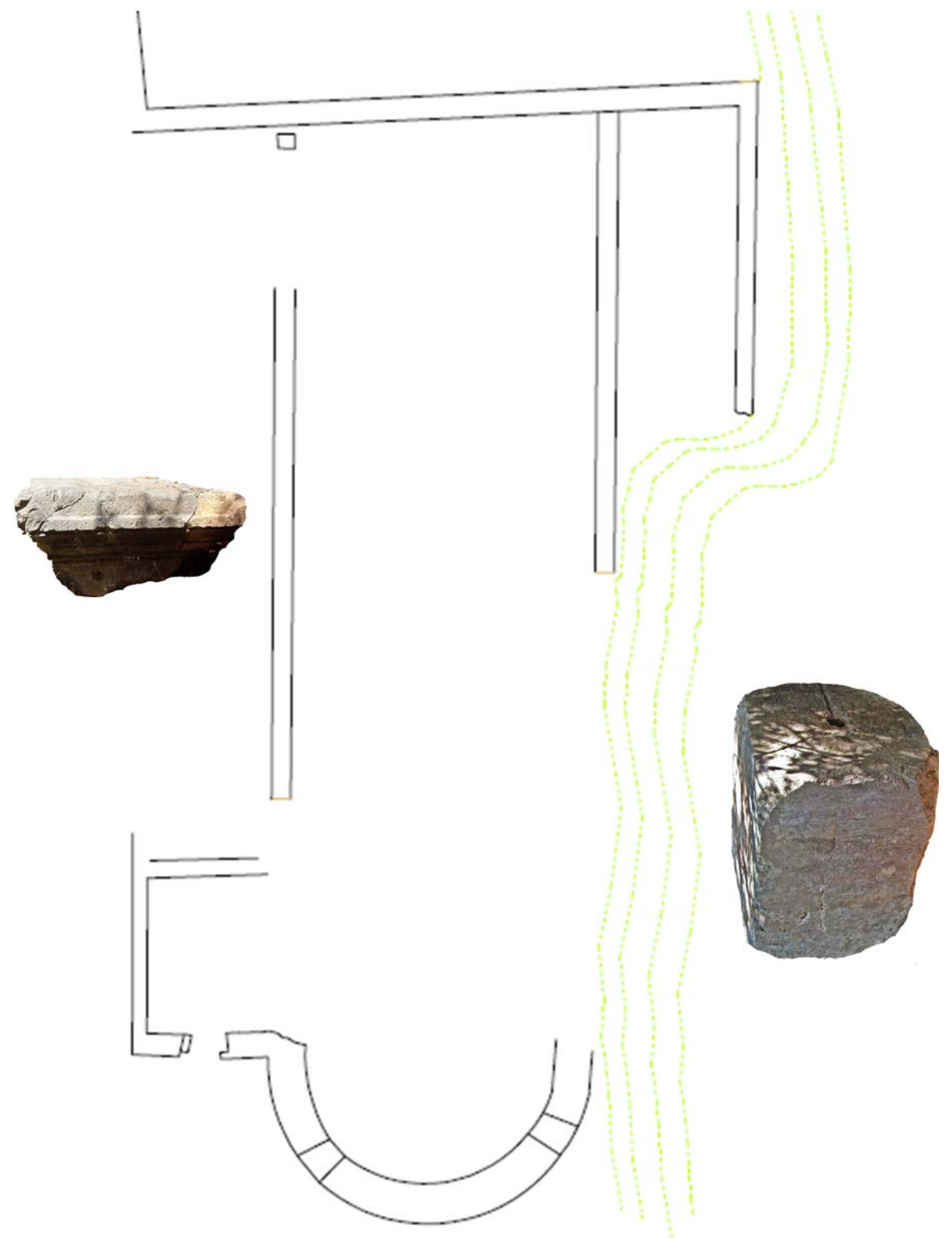

Fig. 10. Akropol Bazilikası (Çizim: Yalçın Mergen)

Söz konusu yazıtta Phaselis'in önde gelen hayırhahlarından Tyndaris isimli Phaselisli bir kadın, imparator Hadrianus'u onurlandırır ${ }^{43}$. Buna göre yazıt tam olarak şu şekilde tamamlanabilir:

43 Krş. Tüner Önen 2008, 319 vd. 


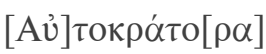

[K $\alpha i \sigma \alpha \rho \alpha]$

$\theta \varepsilon \circ \hat{v} \mathrm{~T} \rho \alpha 1 \alpha v[\mathrm{ov}]$

П $\alpha \rho \theta 1 \kappa o \hat{v}$ vió[ $[v]$,

$\theta \varepsilon o \hat{~ N}$ épova $\{1\}$

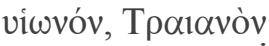

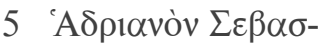

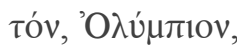

$\sigma \omega \tau \hat{\eta} \rho \alpha \tau \hat{\eta} \varsigma$

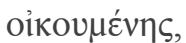

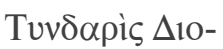

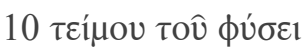

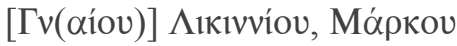

[vio]v̂, 'Pouprívou.

Tanrısal Traianus Parthicus'un oğlu, Tanrisal Nerva'nın torunu, evrenin kurtarıcisı Imparator Caesar Traianus Hadrianus Augustus Olympios'u, Marcus tarafindan evlat edinilen Gnaius Licinius oğlu Dioteimos Rufinus'un kizı Tyndaris (heykelini dikerek onurlandırdı).

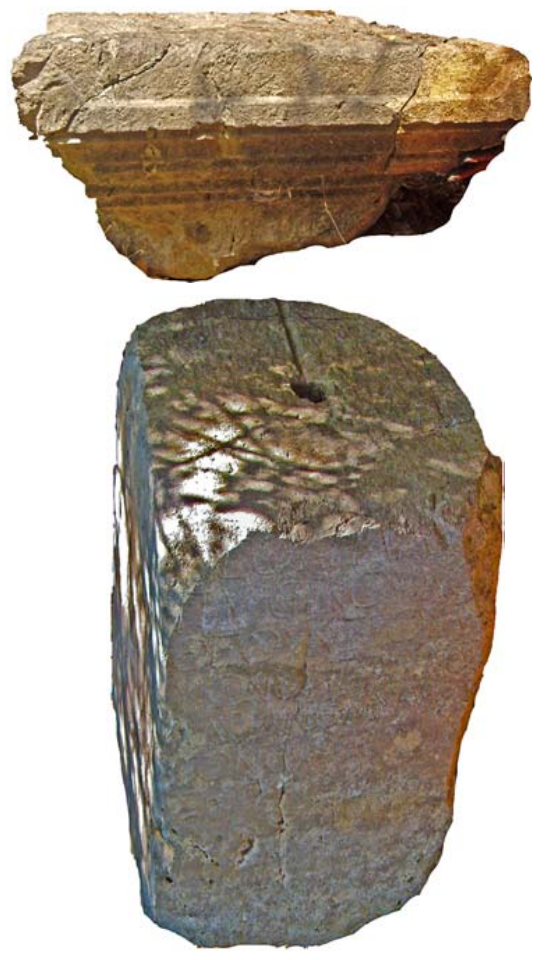

Söz konusu heykel adamasını yaptıran Tyndaris'in Imparator Hadrianus'a ithafen Phaselis'teki Tetragonal Agora'yı da yaptırdığı bilinmektedir (TAM II/3 1194). Tyndaris üzerinde imparatorun heykeli bulunan bu kaideyi de imparatorun doğu seyahatine yönelik olarak aynı dönemde yaptırmış olmalıdır. Roma imparatorluk döneminde kentlerin önde gelen ailelerinin bayan fertlerinin böylesi kamusal işlere girişmesi oldukça sık karşılaşılan bir durumdur. Perge'de Plancia Manga ve Attaleia'da Iulia Sancta bu duruma örnek olarak verilebilir.

\section{No: 4- Agon Yazıtı}

Kalker taşından, üst yarısından kırılmıs, alttan profilli kaide. Güney limanda rıhtımın güçlendirilmesi için yapılan geç dönem duvarında devşirme olarak kullanılmış.

Yük.: 0,78 m.; Gen.: 0,52 m.; Harf Yüksekliği: 0,030-0,038 mm.

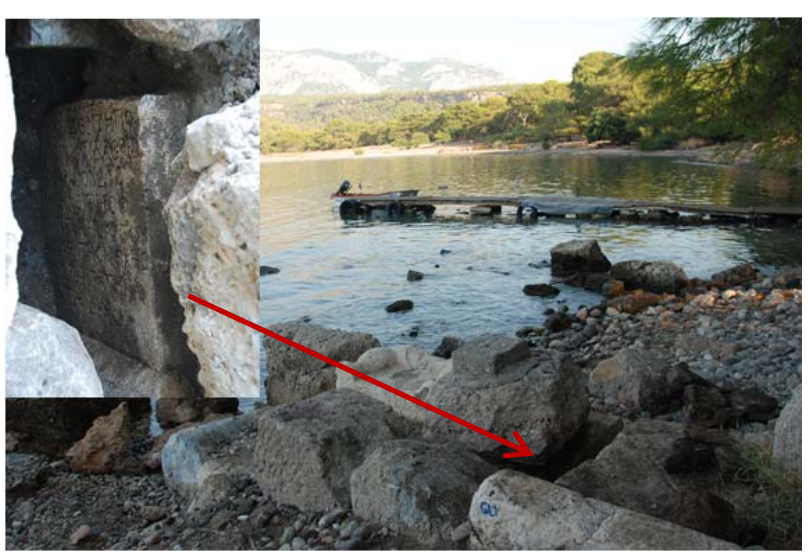




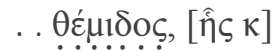

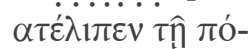

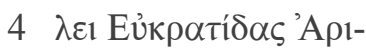

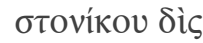

$\Phi \alpha \sigma \eta \lambda \varepsilon i \operatorname{t\eta } \varsigma$,

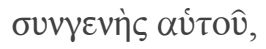

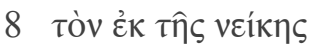

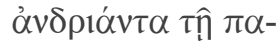

$\tau \rho \mathfrak{\delta} \delta$.

Aristonikos oğlu Aristonikos'un oğlu, kendisinin de akrabası olan Phaselis'li Eukratidas'ın miras bıraktığı themis'in -------- [müsabakasını kazanan,

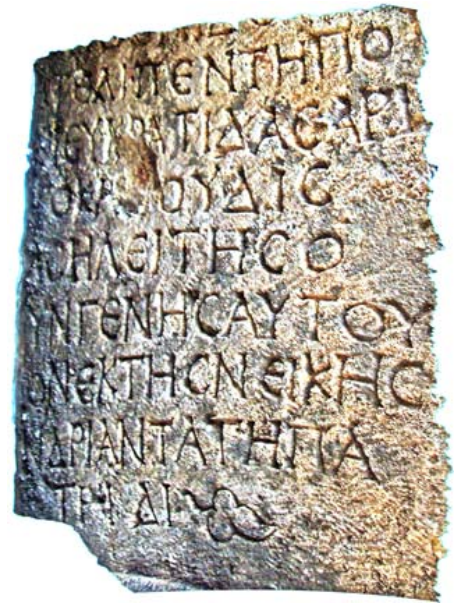

Falanca oğlu Falanca.....], müsabakadan kazandığı heykeli vatana (adadı).

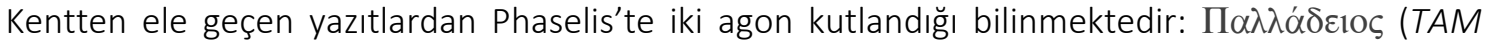

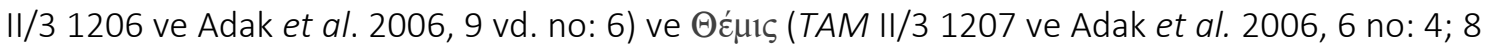
no: 5). Her iki agon da kentin ileri gelen iki şahsiyeti tarafından vakfedilmişlerdir. Bunlardan $\Pi \alpha \lambda \lambda \alpha \dot{\alpha} \delta \varepsilon ı \varsigma^{\prime} u$ Aurelia Apphia; $\Theta \varepsilon ́ \mu ı \varsigma^{\prime} i$ ise Akritos oğlu Eukratidas bağışlamıştır. Bu yazıtla kente agon vakfedenlerin sayısı üçe yükselir.

Yazıtın üst yarısı kırık olduğundan, söz konusu yarışmanın hangi kategoride olduğu okuna-

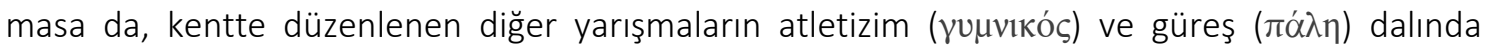
yapılmış olması ${ }^{44}$, buradaki müsabakanın da bu dallardan birinde -büyük olasılıkla da ya yetişkin erkekler ya da çocuklar kategorisindeki güreş müsabakasında- kazanılmış olabileceği ihtimalini güçlendirir.

Str. 3-4: Agonu vakfeden Eukratidas'ın ismi kentten daha önce de belgelenmiştir. Kente yine themis türünde -yani ödülü ( $\theta \varepsilon \dot{\mu} \mu \alpha)$ olan- bir agon vakfeden Akritos oğlu'nun adı da Eukratidas'tır.

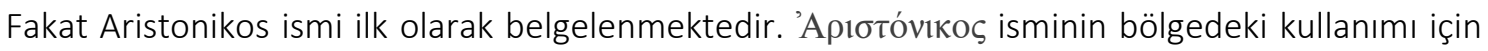
bkz. LGPN VB, 57 s.v. 'Apıбт́́viкos.

\section{No: 5- Nais'ın Mezar Yazıtı}

2014 yılı araştırmaları sırasında tespit edilen mezar steli, kuzey nekropolis alanı içerisinde, kuzey limandaki mendireğin karşısına düşecek konumda bulunan iki katlı geç dönem yapısının kapı eşiğinde devşirme olarak kullanılmıştır. Mermere yakın nitelikli bir kireçtaşından yapılmıştır ve sol alt köşeden kırık durumdadır.

Yük.: 0,38 m.; Der.: 0,44 m.; Harf Yüksekliği: 0,015-0,020 mm.

44 Kentte düzenlenen agonlar hakkında ayrıntılı bilgi için bk. Tüner Önen 2008, 170 vd. 

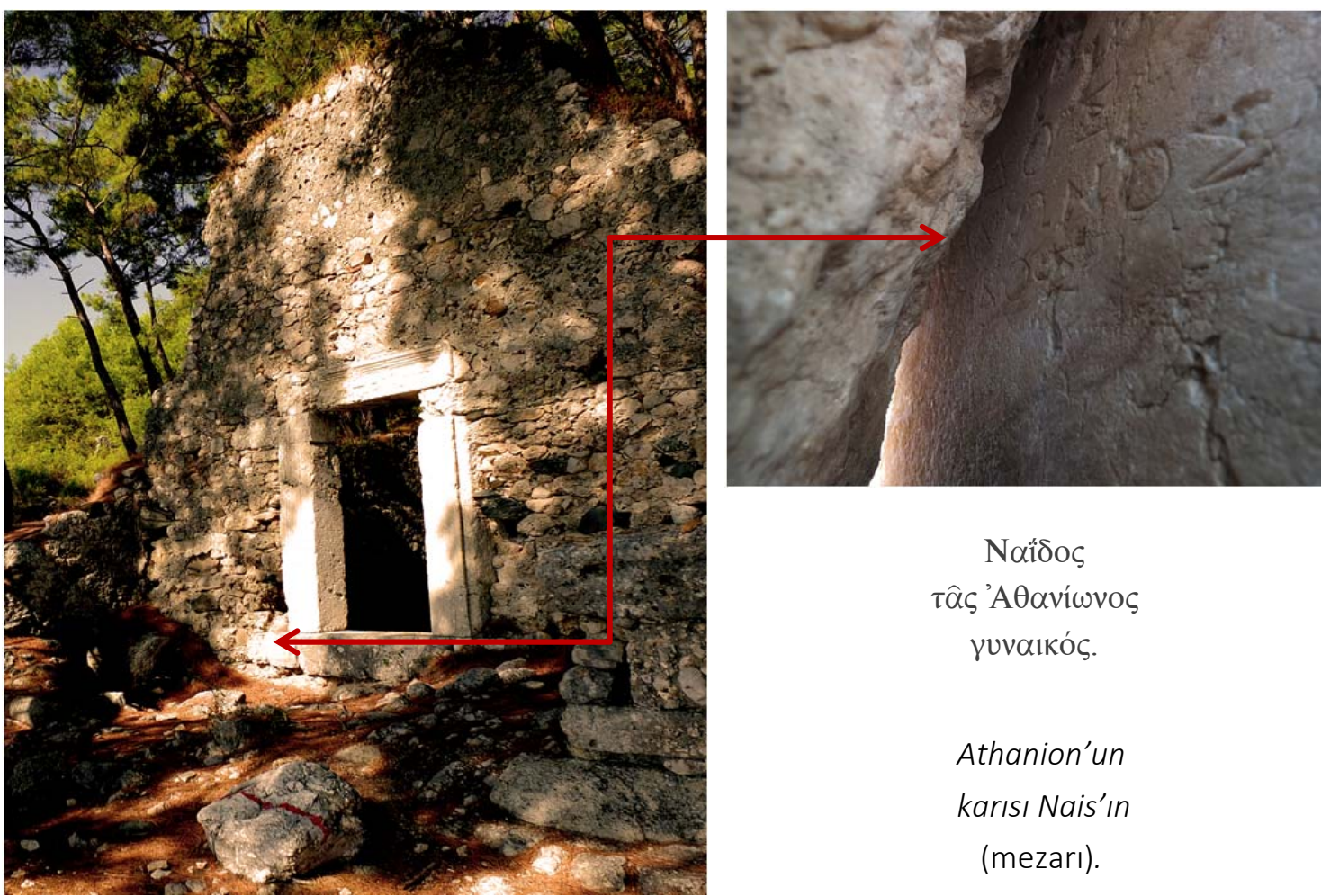

Naî́o

$\tau \hat{\alpha} \varsigma^{\prime} A \theta \alpha v i ́ \omega v o \varsigma$

yuvaı́ós.

Athanion'un

karısı Nais'ın

(mezarı).

Tarih: Harf karakterleri ( $\boldsymbol{\Sigma}-\boldsymbol{\Omega}$ ) dolayısıyla M.Ö. IV yüzyıl

Str. 1: Naìç ismi daha önce Phaselis'te bulunan ve Attaleia'ya taşındığı bildirilen, fakat şu an için yeri bilinmeyen bir mezar yazıtında belgelenmiştir (TAM II/3 1217). Söz konusu ismin bölgedeki kullanımı için bk. LGPN VB, 309 s.v. Naìs.

Str. 2: 'A $\theta \alpha v i \omega v$ ismi Dor formunda yazılmıştır ${ }^{45}$. Bu isim Phaselis'te yine Dor diyalektinde verilmiş ve M.Ö. IV. yüzyıla tarihlenen başka bir yazıtta daha geçmektedir (TAM II/3 1185). Yeni bulunan yazıtta mezar sahibinin kocası olarak geçen şahıs ile bu yazıtta geçen şahıs aynı kişi olabilir, zira her iki yazıt da erken dönem harf karakterleri göstermesinin yanı sıra Dor diyalektinde yazılmışlardır. Daha önceki yazıttan anlaşıldığı üzere Athanion Phaselis kentinin en önemli memuriyeti olan ve yıla ismini veren demiourgos'luk ${ }^{46}$ görevini üstlenmiştir. Söz konusu yazıtta Athanion'un Aristokrateia ve Nikares adlarındaki iki oğlunun babaları için Hestia ve Hermes'e adakta bulundukları görülür.

45 Dor diyalektinde $\alpha^{\prime}$ nın $\eta$ ile yer değiştirmesi için bk. Buck $1955^{3}, 21$ ve 37.

46 Bu memuriyet kenti temsil eder ve din ile hukuki alanlarda yetkilidir. İlk olarak Arkaik Dönem'de Hellas ana karasında ortaya çıkmış ve özellikle büyük kolonizasyon hareketi sırasında yayılmıştır. Koloniyi kuran anakent demiourgos'luk yapacak memuru seçerek koloniye göndermiştir. Demiourgos bu çerçeve içinde eponym bir memuriyet olarak görülmüştür. Fakat antikçağ boyunca farklı zamanlar ve farklı yerler için farklı anlamlarda kullanılmıştır. Bu kelimenin ortaya çıkışı, anlamları ve kullanımları için bk. Schoeffer 1901, 28562862; Jeffery 1973/74, 319-330; Baltes 1999, 446-448. Yetkileri ve sorumlulukları için bk. Veligianni-Terzi 1977, 131 vdd. Phaselis'teki demiourgos'luk memuriyetinin de eponym bir memuriyet olarak hizmet görmesi hakkında ayrıca bk. Veligianni-Terzi 1977, 127. 


\section{No: 6- İnşa Yazıtı}

2014 yılı araştırmaları sırasında Askeri Liman olarak adlandırılan Orta Liman ile aquaeductus arasındaki alanda yer alan ve muhtemelen depo olarak planlanmış yapı kalıntıları arasında sürdürülen çalışmalarda bulunmuştur. Söz konusu yazıt kireçtaşından dikdörtgen bir blok üzerine işlenmiş tabula ansata içerisine kazınmıştır. Söz konusu yazıın 1992 yılında Antalya Müzesi tarafından yürütülen temizlik ve çevre düzeni çalışmaları sırasında da görüldüğü kaydedilmiştir ${ }^{47}$.

Yük.: 0,58 m.; Gen.: 1,12 m.; Der.: 0,30 m.; Harf Yüksekliği: 0,027-0,030 mm.

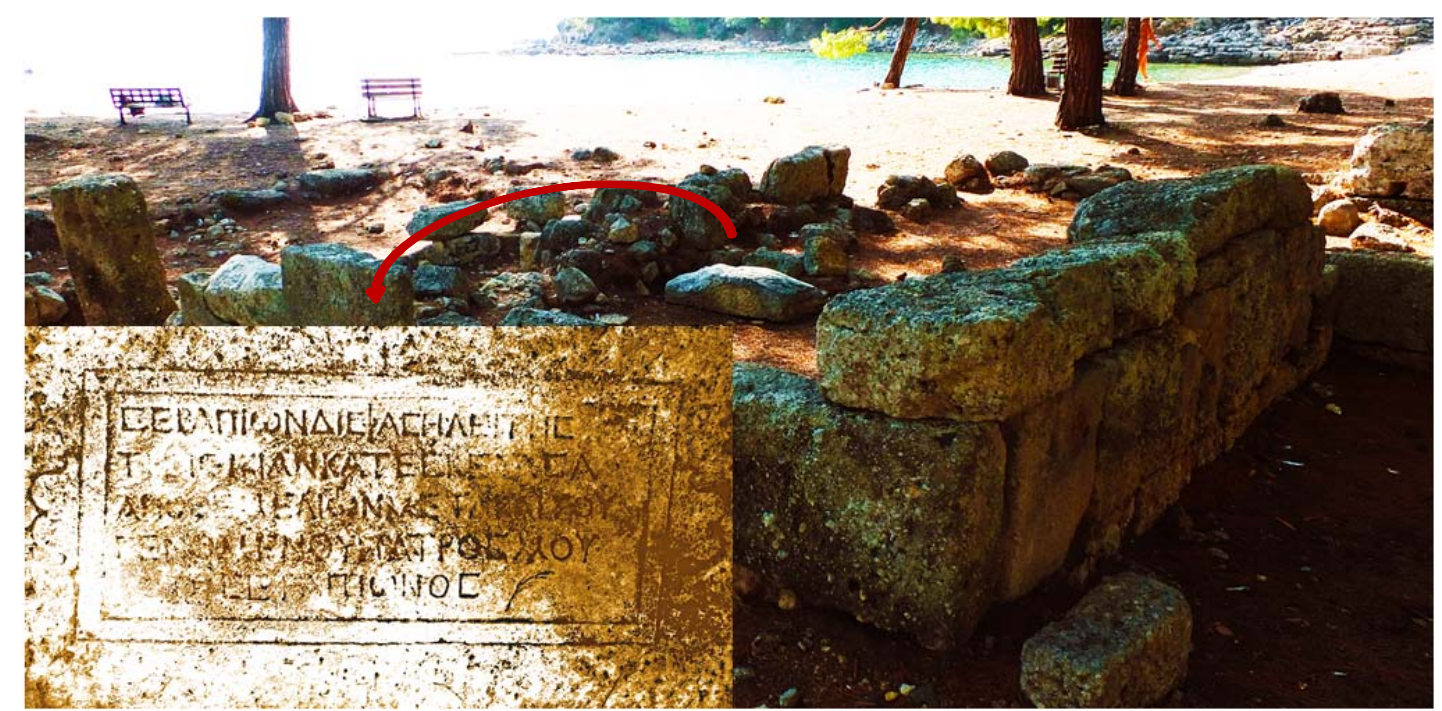

Tarih: Harf karakterleri dolayısıyla M.S. III. yüzyıl.

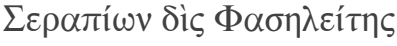
$\tau \grave{v} v$ oikí $\alpha v \kappa \alpha \tau \varepsilon \sigma \kappa \varepsilon v ́ \alpha \sigma \alpha$

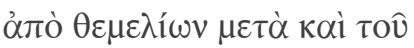

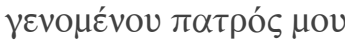
$\Sigma \varepsilon \rho \alpha \pi i \omega v o \varsigma$

\section{Ben Serapion'un oğlu}

Phaselis'li Serapion (bu) ikametgahı temellerinden itibaren öz babam Serapion ile birlikte yaptırdım.

Söz konusu yazıt Sarapion isimli bir Phaselislinin, kendisiyle aynı adı taşıyan babası ile birlikte bir ikametgah inşa ettirdiklerini kaydeder. Fakat yazıtın buluntu yeri in situ olmadığı için söz konusu ikametgahtan ne çeşit bir mekan anlaşılması gerektiği konusu net değildir. Zira kelime anlamı olarak í oíkía ile aynı manada -yapı, ev, konut, ikametgah, yurt... etc.- kullanılan ỏ oî́ko kelimesinin bazen bir mezar yapısını karşıladığı görülmektedir (krş. TAM II/1 350; IvKibyra 281, 296, 351. etc.). Fakat burada söz konusu olan yazıtta gömüye ilişkin herhangi bir emarenin olmaması ve yazıt taşıyıcısının genel durumu, bu yazıtın bir mezar yazıtından ziyade inşa yazıtı olarak değerlendirilmesi gerektiğini düşündürmektedir.

Hem yazıtı yazdıran şahsın hem de babasının adı olarak geçen Serapion ( $\left.\sum \varepsilon \rho \alpha \pi i ́ \omega v\right)$ adı Phaselis'te ilk kez belgelenmektedir. Söz konusu ismin bölgede kullanımı için bk. LGPN VB, 382 s.v. $\sum \varepsilon \rho \alpha \pi i \omega v$.

47 Atila et al. 1994, 430 vd. 


\section{Yayınlı Yazıtlara ilişskin Addenda et Corrigenda}

\section{TAM II/3 1202}

Illk olarak 1892 yılında Bérard, 1944 yılında Kalinka tarafından yayınlanan ${ }^{48}$ ve kentin önde gelenlerinden biri olarak kentte pek çok memuriyette bulunmuş VI. Kolalemis'in onurlandırımasına ilişkin yazıt üzerinde yapılan çalışmalarsırasında, bazı bölümlerin yanlış okunduğu ya da tamamlandığı tespit edilmiştir.

Str. 3: Bu satıı Bérard $\mu \varepsilon[\gamma i ́ \sigma] \tau \alpha ı$; Kalinka ise $\pi \varepsilon \dot{\varepsilon} \mu[\pi] \tau \alpha 1 \varsigma$ olarak deşifre edip tamamlamışlardır; fakat bu satırda açıkça $\pi \varepsilon ́ v \pi \tau \alpha ı \varsigma$ okunmaktadır ${ }^{49}$.

Str. 4: Kalinka bu satırda Kolalemis'in babasının ismini 'E $\xi \alpha \kappa \varepsilon ́[\sigma \tau o v]$ olarak okuyup tamamlamıştır, fakat burada çok açık bir şekilde $\dot{\xi} \xi \dot{\alpha} \kappa ı \varsigma$ $\Phi \alpha \sigma \eta \lambda \varepsilon \dot{\mid} \mid[\tau \eta \nu]$ okunmaktadır.
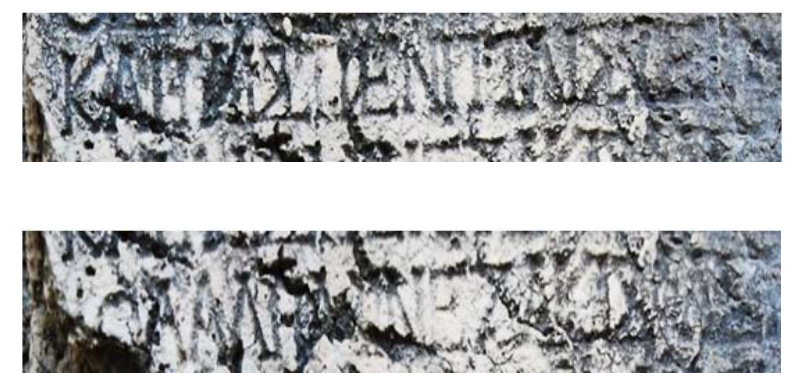
Yerel bir isim olan Kolalemis ismine bugüne kadar sadece Phaselis ve teritoryumunda rastlanmıştı ${ }^{50}$.

Str. 10/11: Bérard ve Kalinka bu satırda $[i \varepsilon \rho \alpha] \tau \varepsilon \dot{\sigma} \alpha \nu \tau \alpha$ tamamlamasını yapmışlardır; fakat bu satırda da çok açık bir şekilde $\pi \rho v-$

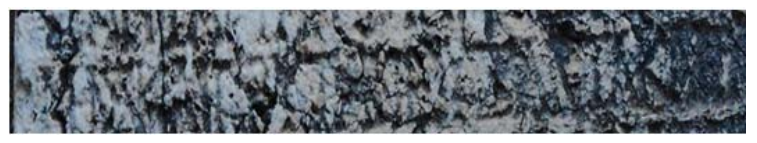

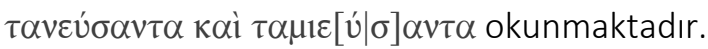

\section{Gephyra II, 6 vd. No: 4}

Büyük hamamın Paleastra duvarında devşirme olarak kullanılan ve 2005 yılında yayınlanan söz konusu yazıt, estampajı üzerinde yapılan çalışmalar ve yeni bulunan bir agon yazıtından edinilen bilgiler ışığında yeniden gözden geçirilmiştir. Bunun sonucunda 2 ve 3 . satırda düzeltmeler ve eklemeler yapılmıştır.

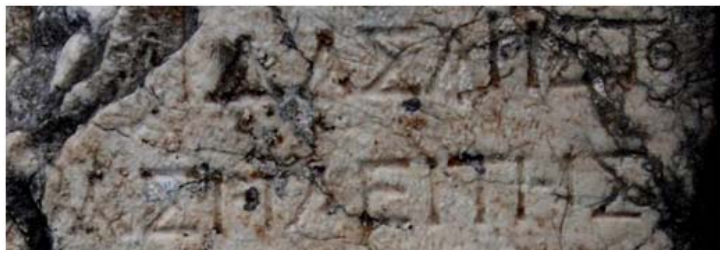

Yeni Fotoğraf

Yeni fotoğraftan da açıkça görüldüğü üzere

2. satırın sonunda APILTO harfleri çok nettir.

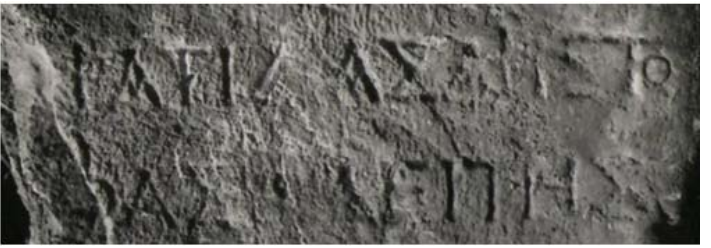

1984 Yılında Çekilen Fotoğraf

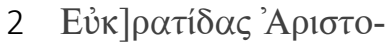

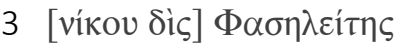

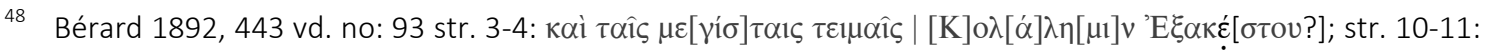

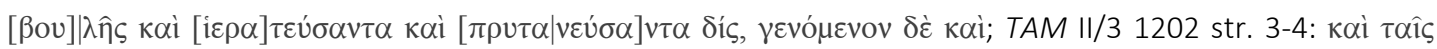

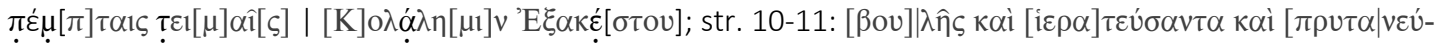

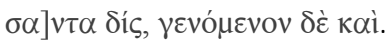

49 Beşli onurlandırma için krş. TAM II/3 $905 \mathrm{~V} \mathrm{~B} 3$.

50 Krş. TAM II/3 1200, 1202, 1204, 1206, 1207, 1210; SEG VI 735; XLII 1440, 1442. 
Buna göre bu yazıtta söz konusu olan Eukratidas, bizim Phaselis'ten daha önceden tanıdığımız ve themis agonu'nu vakfeden Akritos oğlu Akritos'un oğlu Phaselis'li Eukratidas ${ }^{51}$ değil; Aristonikos oğlu Aristonikos'un oğlu Eukratidas'tır (krş. yuk. no: 4).

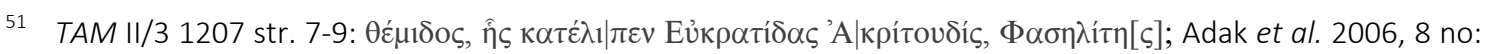

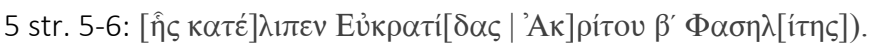




\section{BİBLIYOGRAFYA}

Adak et al. 2006

Adalya

$A E$

Anmed

Anti 1923

Arch. Class.

Arslan - Tüner Önen 2013

Arslan - Tüner Önen 2014

Arslan - Tüner Önen 2015

Atila et al. 1994

Baltes 1999

Bayburtluoğlu 1983

$\mathrm{BCH}$

Beaufort 1818

Bechtel - Collitz 1899

Benndorf - Niemann 1884

Bérard 1890

Bérard 1892

Bezzenberger 1880

Blackman 1973

Blackman 1981

Buck $1955^{3}$

Buren 1908

CIG

DNP

Dornseiff - Hansen 1957

$E A$

Fellows 1839

Gephyra

Heipp-Tamer 1993
M. Adak - N. Tüner Önen - S. Şahin, "Neue Inschriften aus Phaselis". Gephyra 2 (2006) 1-20.

Suna-Inan Kıraç Akdeniz Medeniyetleri Araştırma Enstitüsü Yıllığı. İstanbul. L'Année Épigraphique. Paris 1888 -.

Anadolu Akdenizi Arkeoloji Haberleri. İstanbul.

C. Anti, "Esplorazioni Archeologiche nella Licia e nella Pamfilia". MonAL 29 (1923) 657-786.

Archaelogica Classica. Rivista della Scuola nazionale di Archeologia Rome. Rome.

M. Arslan - N. Tüner Önen, "2012 Yılı Phaselis Antik Kenti ve Teritoryumu Yüzey Araştırması". AST 31/1 (2013) 78-89.

M. Arslan - N. Tüner Önen, "Phaselis ve Teritoryumu Yüzey Araştırması 2013". Anmed 12 (2014) 189-195.

M. Arslan - N. Tüner Önen, "Phaselis ve Teritoryumu Yüzey Araştırması 2014". Anmed 13 (2015) 198-207.

i. A. Atila, S. B. İzgiz - B. Karakurt, "1992 Yılı Phaselis Çevre Düzeni ve Temizlik Çalışmaları". Ed. T.C. Kültür Bakanlığı Anıtlar ve Müzeler Genel Müdürlüğü, IV. Müze Kurtarma Kazılar Semineri 26-29 Nisan 1993 Marmaris. Ankara (1994) 429-455.

M. Baltes, "Demiourgoi (2)". DNP 3 (1999) 446-448.

C. Bayburtluoğlu, "1982 Phaselis Kazısı Raporu". KST V (1983) 181-189.

Bulletin de Correspondance Hellénique. Paris.

F. Beaufort, Karamania or a Brief Description of the South Coast of Asia Minor and of the Remains of Antiquity. London 1818.

F. Bechtel - H. Collitz, Sammlung der Griechischen Dialektinschriften III. Göttingen 1899.

O. Benndorf - G. Niemann, Reisen in Lykien und Karien. Wien 1884.

V. Bérard, "Le Consul Voconius Saxa". BCH 14 (1890) 643-645.

V. Bérard, "Inscriptions d'Asie Mineure (2)". BCH 16 (1892) 417-446.

A. Bezzenberger, Beiträge zur Kunde der Indogermanischen Sprachen. Volume 5. Göttingen 1880.

D. J. Blackman, "Recent Epigraphical Discoveries at Phaselis". Ed. Anonymos, Akten VI. Intern. Kongresses für Griechische und Lateinische Epigraphik München 1972. Vestigia XVII. Münich (1973) 566-568.

D. J. Blackman, "The Inscriptions". Ed. J. Schäfer, Phaselis. Beiträge zur Topographie und Geschichte der Stadt und ihrer Häfen. Tübingen (1981) 138-163.

C. D. Buck, The Greek Dialects. Grammar Selected Inscriptions Glossary. Chicago $1955^{3}$.

A. W. van Buren, "Inscriptions from Asia Minor, Cyprus and the Cyrenaica”. JHS 28 (1908) 180-201.

Corpus Inscriptionum Graecarum. Berlin 1825-1877.

Der Neue Pauly. Stuttgart 1996-.

F. Dornseiff - B. Hansen, Rückläufiges Wörterbuch der Griechischen Eigennamen. Berlin 1957.

Epigraphica Anatolica. Zeitschrift für Epigraphik und Historische Geographie Anatoliens. Bonn.

C. Fellows, Journal Written during an Excursion in Asia Minor 1838. London 1839.

Gephyra. Zeitschrift fur Geschichte und Kultur der Antike auf dem Gebiet der Stigen Turkei. İstanbul.

C. Heipp-Tamer, Die Münzprägung der Lykischen Stadt Phaselis in Griechi- 
Hirschfeld 1874

Holleaux 1886

IGR III

IK

IvKibyra

Jeffery 1973/74

JHS

Judeich 1892

KST

LGPN VB

MJH

MonAL

Paribeni - Romanelli 1914

Petersen - von Luschan 1889

$R E$

von Schoeffer 1901

Şahin 1999

SEG

TAM

Tüner Önen 2008

Tüner Önen 2013

Tüner Önen 2015

Tüner Önen - Akçay 2014

Tüner Önen - Yılmaz 2015

Veligianni-Terzi 1977 scher Zeit. Saarbrücken 1993.

G. Hirschfeld, Vorläufiger Bericht über eine Reise im Südwestlichen Kleinasien I. Berlin 1874.

M. Holleaux, "Inscriptions d'Oenoanda". BCH 10 (1886) 216-235.

Inscriptiones Graecae ad res Romanas Pertinentes. Paris 1906.

Inschriften Griechischer Städte aus Kleinasien. Bonn 1972-.

Die Inschriften von Kibyra. Teil I. IK 60. Ed. T. Corsten. Bonn 2002.

L. H. Jeffery, "Demiourgoi in the Archaic Period". Arch. Class. 25/26 (1973/74) 319-330.

Journal of Hellenic Studies. London.

W. Judeich, Kleinasiatische Studien, Untersuchungen zur GriechischPersischen Gesichte des IV. Jhdts v. Chr. Marburg 1892.

Kazı Sonuçları Toplantısı. Ankara 1980-.

A Lexicon of Greek Personal Names. Vol. VB: Coastal Asia Minor: Caria to Cilicia. Eds. J.-S. Balzat, R. W. V. Catling, É. Chiricat - F. Marchand. Oxford 2013.

Akdeniz Insani Bilimler Dergisi / Mediterranean Journal of Humanities. Antalya.

Monumenti Antichi Publicati per Cura Della Reale Accademia dei Lincei. Rome.

R. Paribeni - R. Romanelli, "Studii e Ricerche Archeologiche nell'Anatolia Meridionale". MonAL 23 (1914) 5-274.

E. Petersen - F. von Luschan, Reisen in Lykien Milyas und Kibyratis Reisen im Südwestlichen Kleinasien II. Wien 1889.

Paulys Real-Encyclopadie der Classischen Altertumswissenschaft. Stuttgart (Munchen).

V. von Schoeffer, "Demiurgoi". RE IV/2 (1901) 2856-2862.

S. Şahin, "EMA I: Inschriften aus Pamphylien und Lykien". EA 31 (1999) 40-52.

Supplementum Epigraphicum Graecum.

Tituli Asiae Minoris. Wien.

N. Tüner Önen, Phaselis Antik Kenti ve Teritoryumu. Yayınlanmamış Doktora Tezi, Akdeniz Üniversitesi. Antalya 2008.

N. Tüner Önen, "Hadrians Reisen im Östlichen Mittelmeer Anhand Neuer Inschriften aus Phaselis". Adalya XVI (2013) 93-106.

N. Tüner Önen, "Lucius Verus'un Doğu Seferine İlişkin Phaselis'ten Yeni Bir Belge". Eds. B. Takmer, E. N. Akdoğu Arca - N. Gökalp Özdil, Vir Doctus Anatolicus. Studies in Memory of Sencer Şahin. Sencer Şahin Anısına Yazılar. İstanbul (2015) 972-979.

N. Tüner Önen - A. Akçay, "Phaselis Kentinin Su Teminine İlişkin Gözlemler ve Dijital Epigrafi Çalışmaları". MJH IV/2 (2014) 279-292.

N. Tüner Önen - F. Yılmaz, "A New Athena Polias Votive Inscription from the Phaselis' Acropolis". Adalya XVIII (2015) 121-131.

C. Veligianni-Terzi, Damiurgen. Zur Entwicklung einer Magistratur. Griechenland 1977. 